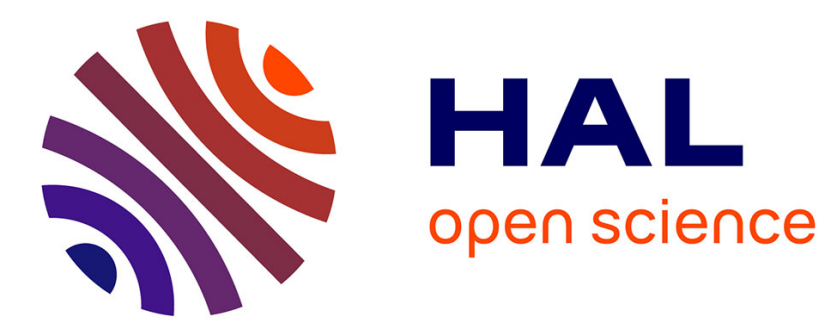

\title{
Microbial ecology of tourist Paleolithic caves
}

Zélia Bontemps, Lise Alonso, Thomas Pommier, Mylène Hugoni, Yvan

\author{
Moënne-Loccoz
}

\section{To cite this version:}

Zélia Bontemps, Lise Alonso, Thomas Pommier, Mylène Hugoni, Yvan Moënne-Loccoz. Microbial ecology of tourist Paleolithic caves. Science of the Total Environment, 2022, 816, pp.151492. 10.1016/j.scitotenv.2021.151492 . hal-03472792

\section{HAL Id: hal-03472792 \\ https://hal.science/hal-03472792}

Submitted on 9 Dec 2021

HAL is a multi-disciplinary open access archive for the deposit and dissemination of scientific research documents, whether they are published or not. The documents may come from teaching and research institutions in France or abroad, or from public or private research centers.
L'archive ouverte pluridisciplinaire HAL, est destinée au dépôt et à la diffusion de documents scientifiques de niveau recherche, publiés ou non, émanant des établissements d'enseignement et de recherche français ou étrangers, des laboratoires publics ou privés.

\section{(ㅇ)(1) $\$$}

Distributed under a Creative Commons Attribution - NonCommercial - NoDerivatives| 4.0 
Review

\title{
Microbial ecology of tourist Paleolithic caves
}

\author{
Zélia Bontemps, Lise Alonso ${ }^{1}$, Thomas Pommier, Mylène Hugoni, Yvan Moënne-Loccoz * \\ Univ Lyon, Université Claude Bernard Lyon 1, CNRS, INRAE, VetAgro Sup, UMR Ecologie Microbienne, F-69622 Villeurbanne, France
}

\section{H I G H L I G H T S}

- High-throughput sequencing is shedding new light on the cave microbiota.

- Cave exploration at a finer taxonomic level is needed to assess microbial endemism.

- Bacteroidetes and Nitrospirae might serve as bio-indicators of cave anthropization.

- Tourism may cause significant shifts in the microbiota of Paleolithic caves.

- Tourism-related microbial alterations require further research attention.

\section{A R T I C L E I N F O}

\section{Article history:}

Received 16 August 2021

Received in revised form 19 October 2021

Accepted 3 November 2021

Available online $\mathrm{xxxx}$

\section{Editor: Ewa Korzeniewska}

\section{Keywords:}

Tourist caves

Anthropization

Microbial colonization

Microbiome

Paleolithic art

Rock surface alteration

\section{G R A P H I C A L A B S T R A C T}

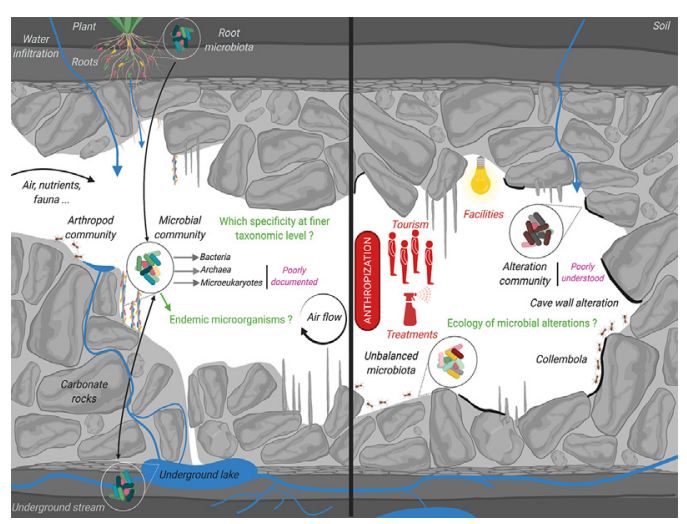

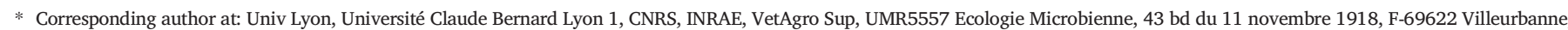
France.

E-mail address: yvan.moenne-loccoz@univ-lyon1.fr (Y. Moënne-Loccoz).

1 Current address: INRS, 1 rue du Morvan, CS 60027, F-54519 Vandoeuvre-lès-Nancy, France.

http://dx.doi.org/10.1016/j.scitotenv.2021.151492

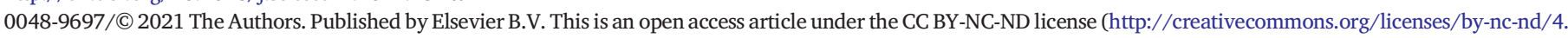
$0 /)$. 


\section{Contents}

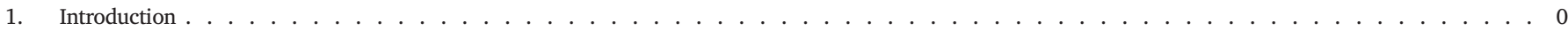

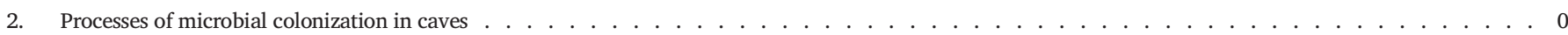

2.1. Microbial entry into caves and adhesion to cave surfaces . . . . . . . . . . . . . . . . . . . . . . . . .

2.2. Microbial growth and establishment in caves . . . . . . . . . . . . . . . . . . . . . . . . . . . . . 0

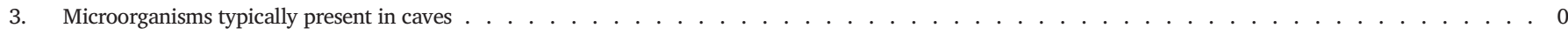

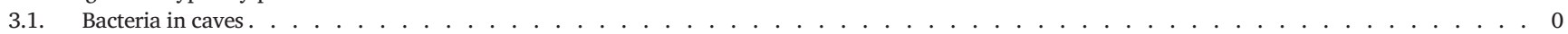

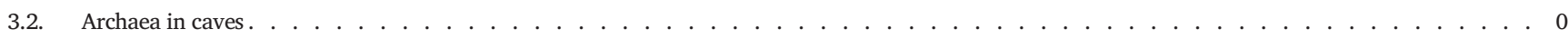

3.3. Fungi and other microeukaryotes in caves . . . . . . . . . . . . . . . . . . . . . . . . . . . . . . . . . . 0

3.4. Endemic features of the cave microbiome . . . . . . . . . . . . . . . . . . . . . . . . . . . . . . 0

4. Tourist Paleolithic caves and effects of contemporary anthropization on microorganisms . . . . . . . . . . . . . . . . . . . . . . . . . 0

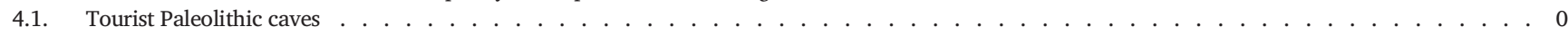

4.2. Anthropization of Paleolithic caves related to tourism . . . . . . . . . . . . . . . . . . . . . . . . 0

5. Microbial alteration of rock surfaces in tourist Paleolithic caves . . . . . . . . . . . . . . . . . . . . . . . . . . . 0

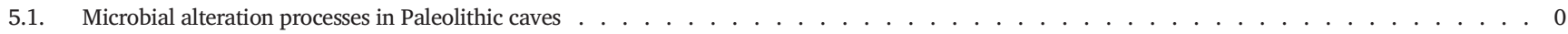

5.2. Attempts to tackle microbial alterations in Paleolithic caves . . . . . . . . . . . . . . . . . . . . . . . . . . . . . . . 0

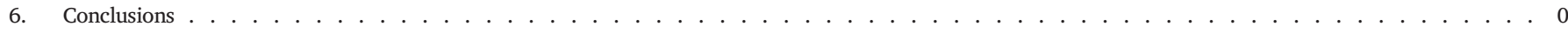

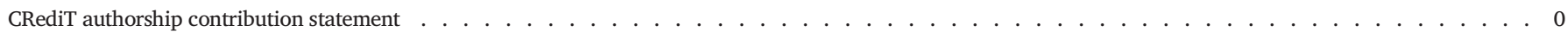

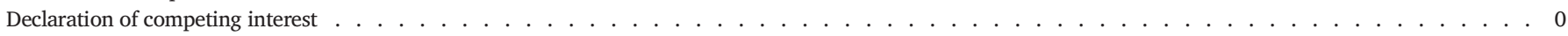

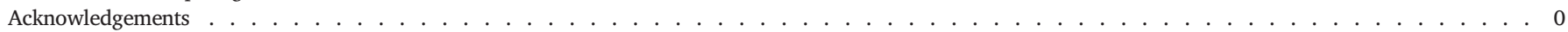

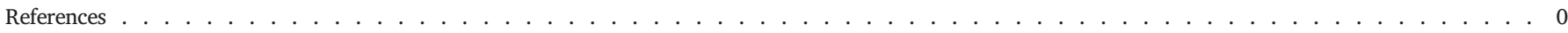

\section{Introduction}

Karsts correspond to particular landscapes formed on carbonate rocks (limestone, dolomite, marble, etc.) or evaporites (gypsum, etc.) and that are characterized by the development of an extensive underground drainage network (Bakalowicz, 1999; Engel and Northup, 2008). Water infiltration through carbonate rocks is instrumental in $\mathrm{CO}_{2}$-mediated chemical dissolution of limestone and dolomite, and it may result in the formation of karstic caves (Cuezva et al., 2012). On one hand, karstic caves are characterized by the corrosion and/or erosion processes at the origin of the karstification phenomenon. On the other hand, they are also typified by the subsequent carbonate precipitation taking place depending on the behavior of underground water, and leading to the formation of speleothems such as stalactites and stalagmites (Perrette et al., 2000).

Karstic caves display particular environmental conditions, characterized by darkness, high level of relative humidity (near saturation), stable temperatures (Bastian and Alabouvette, 2009; Cuezva et al., 2009; Pasić et al., 2010) and elevated $\mathrm{CO}_{2}$ concentrations (Banerjee and Joshi, 2013). Levels of minerals are high (Barton and Jurado, 2007; Bastian et al., 2010) but caves are oligotrophic regarding organic matter (Cañveras et al., 2001; Cuezva et al., 2009; Jurado et al., 2010), with typically less than $2 \mathrm{mg}$ of total organic carbon per liter (Barton and Jurado, 2007). Most organic carbon in caves originates from the surface and makes its way into the endokarst via water percolation through plant root channels and cracks in the epikarst (i.e. the overlying rock), air flows transporting minute organic particles and gaseous organics, or animal dejections e.g. bat guano (Saiz-Jimenez and Hermosin, 1999; Barton and Jurado, 2007; Cuezva et al., 2009; Pasić et al., 2010; Vanderwolf et al., 2013). Caves may also represent heterogeneous systems because of the nature and surface properties of the various internal rock layers, the architecture and connectivity of the cave (Cañveras et al., 2001; Nehme, 2013), as well as airflow and climatic exchanges with the outside atmosphere (Russell, 1998; Banerjee and Joshi, 2013). Outside conditions impact most on the entrance zone of caves (Banerjee and Joshi, 2013), and thus climatic fluctuations within caves depend on the distance to the entrance, as well as epikarst thickness (Cuezva et al., 2009).

Despite the particular, apparently unfriendly environmental conditions prevailing in caves (Schabereiter-Gurtner et al., 2002; Cuezva et al., 2009), these underground ecosystems appear to host a broad range of microorganisms (Engel and Northup, 2008; Saiz-Jimenez, 2012) and current highthroughput sequencing methods have started to document the extent of microbial diversity in caves (Pfendler et al., 2018; Alonso et al., 2019; Thompson et al., 2019). Bacteria, Archaea and microeukaryotes typically coexist within microbial communities in all ecosystems, and caves are no exception to this. This microbial world can play significant roles in caves, starting from the modulation of geochemical processes responsible for cave formation (Jurado et al., 2010). Indeed, microorganisms are involved in the karstification process through chemical weathering (by releasing organic acids), biological physical weathering (by fungal growth-mediated breaking down and mechanical dislodging of loose limestone particles) and enzymatic weathering (by the production of carbonic anhydrase enzymes) (Lian et al., 2011; Hou et al., 2013). In addition, microbial activity might contribute to the formation of various mineral constituents in caves, including moonmilk, saltpeter, mineral precipitates, etc. (Northup, 1997; Cañveras et al., 2001; Brannen-Donnelly and Engel, 2015). Finally, microorganisms play a key role in the production and turnover of organic matter (Barton and Northup, 2007; Jurado et al., 2010; Garcia-Anton et al., 2013). Microbial activities may be of particular importance in certain Paleolithic caves, where excessive tourism has enhanced organic $\mathrm{C}$ inputs facilitating thus microbial proliferation, which might threaten artwork quality (Cañveras et al., 2001; Bastian et al., 2010; Martin-Sanchez et al., 2012a).

This review deals with the microbial ecology of karstic caves, with a focus on tourist Paleolithic caves for which conservation issues represent a challenge. The processes of microbial colonization in caves are described, along with the resulting microbial diversity expected in caves. The impact of tourism on the microbiota of Paleolithic caves is then reviewed, including its consequences in terms of microbial proliferation and alteration of cave surfaces and Paleolithic art.

\section{Processes of microbial colonization in caves}

\subsection{Microbial entry into caves and adhesion to cave surfaces}

Caves represent underground and enclosed environments, but they are connected with the surrounding environment present outside the cave (Garcia-Anton et al., 2013; Hershey and Barton, 2018; Morse et al., 2021). Thus, microorganisms may enter in caves and karst ecosystems following passive dissemination by infiltrating water (Dupont et al., 2007; Davis et al., 2020) or air currents (Engel and Northup, 2008; Cuezva et al., 2009; Vanderwolf et al., 2013). Concerning air dissemination, Fungi are probably largely transported as spores, whereas Bacteria are more likely to enter caves as cells adhering to dust particles (Dupont et al., 2007; Chen et al., 2009; Garcia-Anton et al., 2013). Biotic vectors may also be involved, especially incoming humans or animals such as arthropods (Barton and Jurado, 2007; Dupont et al., 2007) and bats (Vanderwolf et al., 2013). In the case of tourist caves, humans might 
constitute the most important factor favoring microbial arrival. Arthropods can differently promote the dispersion of Bacteria (Scheu and Simmerling, 2004), Archaea (Moissl-Eichinger and Huber, 2011) and Fungi (Thimm et al., 1998) by carrying these microorganisms on their bodies or hosting them in their gut (Thimm et al., 1998). Therefore, most microorganisms present in caves were considered, at least in earlier studies, to have been transported there, which means they have often been regarded as not representing a cave-specific microbiota (Keswick et al., 1982; Palmer, 1991; Cunnigham et al., 1993; Northup et al., 1994; Rusterholtz and Mallory, 1994; Gorbushina, 2007; Herzog Velikonja et al., 2013). For instance, in Lascaux Cave, this allochthonous status has been proposed for the facultative entomophilous Geosmithia species (Bastian et al., 2009b). However, evidence also points to the occurrence of microorganisms as intrinsic cave inhabitants (Schabereiter-Gurtner et al., 2004). The Schneider-Racoviță classification of underground species as trogloxenes, troglophiles or troglobionts (troglobitic) according to their preferred habitat and origin (s) (Mammola, 2019) is little implemented yet for microorganisms (Snider et al., 2009; Zhang et al., 2018), but this concept deserves attention as it might prove useful as well to characterize the status of microbial species. The main process(es) leading to the entry of allochthonous microorganisms into caves varies according to cave specifics. In Altamira Cave, gaseous phase exchanges with the outside atmosphere matter most (Cuezva et al., 2009; Saiz-Jimenez et al., 2011; Garcia-Anton et al., 2013), whereas in Lascaux Cave the arthropods are thought to play a larger role (Bastian et al., 2009b; Bastian et al., 2010).

Once entered in the cave, microorganisms might colonize and proliferate on the surfaces available. The establishment of microorganisms on cave walls requires adhesion to the wall surface (Cuezva et al., 2009). The most studied adhesion mechanism in Bacteria and Fungi is the secretion of extracellular polysaccharides (Gorbushina, 2007; Zucconi et al., 2012), leading to biofilm formation and facilitating adhesion for additional microorganisms like Cyanobacteria and other Bacteria, Fungi and microalgae (Riding, 2000). In the case of Fungi, hyphae can also penetrate directly into microporous wall surfaces (Sterflinger, 1998; Kumar and Kumar, 1999; Gorbushina, 2007), thereby promoting colonization of these rock materials (Stupar et al., 2014). Microclimatic conditions may modulate adhesion conditions, as condensation on walls forms clouds of water microparticles (named hydroaerosols) that support adhesion for microorganisms carried by air particles (Cuezva et al., 2009; Garcia-Anton et al., 2013). In turn, microbial adhesion to rock surfaces may facilitate biotransformations of minerals that provide nutriments or energy (Riding, 2000), as well as microbial growth (Cuezva et al., 2009).

\subsection{Microbial growth and establishment in caves}

Once microorganisms interact with cave surfaces, the particular microclimate and resource availability on rock surfaces will determine the possibilities of microbial growth and colonization (Gorbushina, 2007; Cuezva et al., 2009). Although the majority of cave microorganisms do not function as autotrophs (Laiz et al., 1999; Simon, 2019; Bastian et al., 2009a), photosynthesis takes place in tourist caves where artificial lights are operated, and consequently chemoautotrophy may play an important role by providing organic matter (Cañveras et al., 2001; Barton and Jurado, 2007; Barton and Northup, 2007). Overall, oligotrophic conditions on rock surfaces lead to low growth rates (Portillo and Gonzalez, 2010), where the availability of organic carbon is often limiting (Stomeo et al., 2009). In such cases, inputs of organic matter into the cave (through infiltrating water, air-borne particles, human inputs, incoming fauna or flooding by subterranean streams in certain cases; Cañveras et al., 2001; Morse et al., 2021) will play an important role (Jurado et al., 2010; Garcia-Anton et al., 2013). Experimental analysis of sterilized rock tablets placed in Altamira Cave showed that bacterial and fungal colonization, based on visible growth and scanning electron microscopy, needed several months (Jurado et al., 2009). In certain cases where nutrients are not limiting, cave conditions promote microbial proliferation and may lead to the formation of stains, as reported in Lascaux Cave (Bastian et al., 2010), or visible colonies as described in Altamira Cave
(Schabereiter-Gurtner et al., 2002; Portillo et al., 2008). Rather than forming single microcolonies, Fungi, algae and Bacteria are likely to coexist (Gorbushina, 2007), often in mixed biofilms (Schabereiter-Gurtner et al., 2002; Portillo et al., 2008).

Microbial interactions taking place in caves remain largely undocumented. Cave oligotrophy probably leads to strong competition for substrates among microorganisms (Bhullar et al., 2012). This competition is probably assisted by the release of antimicrobial secondary metabolites, and both microorganisms with antimicrobials production ability (Ghosh et al., 2017) and antibiotic resistance traits (Bhullar et al., 2012) can be isolated from caves. Yet, species coexistence within cave microbial communities raises the possibility that even positive interactions, such as cooperation and mutualism, are also taking place (Barton and Jurado, 2007). Due to the presence of light, lichens may often be found near the entrance of certain caves (Roldán and Hernández-Mariné, 2009). Bacterial chemoautotrophs have been suggested to interact with heterotrophic microorganisms in various caves (Cunnigham et al., 1993; Vanderwolf et al., 2013). Indeed, it is likely that a large number of microorganisms rely on organic substrates (carbon and energy sources) provided by other microbial community members (Barton and Jurado, 2007; Barton, 2006), as in other types of environments.

Once established in caves, microorganisms may be remobilized and spread further, but probably across shorter distances than during initial arrival of external microorganisms into these underground ecosystems. Wind currents within Altamira Cave are thought to favor formation of Bacteriacontaining aerosols from condensed water present on rock surfaces in the cavity, thereby enhancing bacterial spread (Garcia-Anton et al., 2013). In Lascaux, arthropods such as collembola are likely to disseminate cave Bacteria and Fungi, specifically those associated with black stains, i.e. patches on rock surfaces with a black visual appearance and attributed to the production of fungal melanin (Bastian et al., 2010). Therefore, certain areas within caves might also serve as microbial reservoirs, both for indigenous and allochthonous microorganisms, with the possibility of subsequent recolonization processes from one cave area to the other (Engel, 2010; De Mandal et al., 2016).

\section{Microorganisms typically present in caves}

The structure of cave microbial communities is rather stable in time (Tomczyk-Żak and Zielenkiewicz, 2016; Alonso et al., 2018) but it can vary according to (i) local conditions, such as the type (Jones and Macalady, 2016) and heterogeneity (Cuezva et al., 2009) of mineral or organic surfaces, and (ii) many specific physicochemical factors including pH, nutrient availability, etc. (Engel, 2010; De Leo et al., 2012). Caves are thought to be colonized by highly-specialized microorganisms (Schabereiter-Gurtner et al., 2002; Bastian and Alabouvette, 2009; De Leo et al., 2012), and both culture-dependent and culture-independent methods have evidenced that Bacteria and Fungi inhabiting karstic caves are very diverse (Schabereiter-Gurtner et al., 2002; Barton and Northup, 2007; Jurado et al., 2010; Alonso et al., 2019). Culture-independent methods especially with the advent of high-throughput sequencing are now providing an exhaustive view of microbial richness and diversity, and also facilitate the inventory of Archaea and non-fungal microeukaryotes, so far neglected in most investigations (Table 1, Fig. 1). Functional traits of these microorganisms have been reviewed by Vanderwolf et al. (2013), Tomczyk-Żak and Zielenkiewicz (2016), and Joshi and Chettri (2019). Physiologically-active members of the cave microbiota have been specifically targeted, but this was done in a limited number of studies (e.g. Portillo et al., 2008, 2009).

\subsection{Bacteria in caves}

Data obtained across a broad range of caves, especially using cultureindependent methods, indicate that the bacterial community is largely dominated by Proteobacteria and Actinobacteria (Table 2) (Cañveras et al., 2001; Cuezva et al., 2009; Saiz-Jimenez, 2012; Diaz-Herraiz et al., 2014; Dhami et al., 2018; Zhu et al., 2019). The high abundance of Proteobacteria 
Table 1

Mean, minimal and maximal relative abundance (\%) of phyla retrieved in the microbiome of non-anthropized caves with culture-dependent approaches. Minimal and maximal abundances of phyla, number of caves and number of countries are calculated without considering the null values. Hyphens are used when no data is available. Archaea are not included as they are not readily amenable to cultivation. Non-fungal microeukaryotes (Amoebozoa, Stramenopiles, Alveolata, Chlorophyta) have hardly been investigated and are not shown.

\begin{tabular}{|c|c|c|c|c|c|}
\hline \multirow[t]{2}{*}{ Phyla } & \multicolumn{3}{|c|}{$\begin{array}{l}\text { Relative } \\
\text { abundance (\%) }\end{array}$} & \multirow[t]{2}{*}{$\begin{array}{l}\text { Number of caves } \\
\text { (where evidenced) }\end{array}$} & \multirow[t]{2}{*}{ References } \\
\hline & Min & Max & Mean & & \\
\hline \multicolumn{6}{|l|}{ Bacteria } \\
\hline Proteobacteria & 2.4 & 41.1 & 22.4 & 7 & $\begin{array}{l}\text { Adetutu et al., 2012; Barton, 2015; Griffin et al., 2014; Herzog Velikonja et al., 2013; Northup et al., 2003; } \\
\text { Schabereiter-Gurtner et al., } 2004\end{array}$ \\
\hline Actinobacteria & 11.6 & 95.1 & 35.7 & 6 & Adetutu et al., 2012; Barton, 2015; Griffin et al., 2014; Northup et al., 2003; Schabereiter-Gurtner et al., 2004 \\
\hline Chloroflexi & 1.2 & 1.2 & 0.2 & 1 & Schabereiter-Gurtner et al., 2004 \\
\hline Acidobacteria & 16.5 & 16.5 & 7.9 & 2 & Herzog Velikonja et al., 2013; Schabereiter-Gurtner et al., 2004 \\
\hline Bacteroidetes & 4.9 & 6.3 & 4.5 & 6 & $\begin{array}{l}\text { Barton, 2015; Griffin et al., 2014; Herzog Velikonja et al., 2013; Novakova et al., 2005; Schabereiter-Gurtner } \\
\text { et al., } 2004\end{array}$ \\
\hline Firmicutes & 5.0 & 37.9 & 10.2 & 4 & Adetutu et al., 2012; Barton, 2015; Northup et al., 2003 \\
\hline Gemmatimonadetes & - & - & - & - & - \\
\hline Planctomycetes & - & - & - & - & - \\
\hline Nitrospirae & 15.5 & 15.5 & 1.9 & 1 & Northup et al., 2003 \\
\hline Verrucomicrobia & - & - & - & - & - \\
\hline Cyanobacteria & - & - & - & - & - \\
\hline Other taxa & 1.2 & 93.7 & 14.4 & 3 & Adetutu et al., 2012; Novakova et al., 2005; Schabereiter-Gurtner et al., 2004 \\
\hline Unidentified taxa & 0.1 & 0.1 & 0 & 1 & Schabereiter-Gurtner et al., 2004 \\
\hline \multicolumn{6}{|l|}{ Fungi } \\
\hline Ascomycota & 5.5 & 96.1 & 94.9 & 5 & Adetutu et al., 2011; Belyagoubi et al., 2018; Jacobs et al., 2017; Novakova et al., 2005; Vaughan et al., 2011 \\
\hline Basidiomycota & 1.9 & 7.6 & 2.5 & 3 & Adetutu et al., 2011; Jacobs et al., 2017; Novakova et al., 2005; Vaughan et al., 2011 \\
\hline Zygomycota & 2.6 & 2.6 & 1.8 & 3 & Belyagoubi et al., 2018; Jacobs et al., 2017; Novakova et al., 2005; Vaughan et al., 2011 \\
\hline Chytridiomycota & - & - & - & - & - \\
\hline Mucoromycota & 2.7 & 2.7 & 0.5 & 1 & Novakova et al., 2005 \\
\hline \multicolumn{6}{|l|}{ Other situations } \\
\hline Other micro-eukaryotes & 0.2 & 5.0 & 1.1 & 3 & Adetutu et al., 2011; Belyagoubi et al., 2018; Vaughan et al., 2011 \\
\hline $\begin{array}{l}\text { Unidentified } \\
\text { micro-eukaryotic taxa }\end{array}$ & - & - & - & - & - \\
\hline
\end{tabular}

may be partly due to their ability to degrade a wide range of organic compounds and for certain taxa to catalyze metal transformations, whereas Actinobacteria members are involved in biomineralization processes (De Leo et al., 2012; Tomczyk-Żak and Zielenkiewicz, 2016). Other phyla identified through high-throughput sequencing methods include Acidobacteria (some of them involved in dissimilatory iron reduction), Firmicutes (for which growth on various organic compounds is documented) and Nitrospirae (a metabolically diverse, generally aerobic phylum but with the ability for anaerobic reduction of sulfate), which are also abundant in caves, as well as Gemmatimonadetes, Planctomycetes (some of them capable of anaerobic ammonia oxidation coupled with nitrate reduction), Verrucomicrobia and Cyanobacteria whose members are not recovered by conventional laboratory cultivation methods (Tomczyk-Żak and Zielenkiewicz, 2016) (Table 1). These phyla were shown to be abundant in many caves from Australia, China, Spain and the USA (Barton and Jurado, 2007; Bastian and Alabouvette, 2009; Adetutu et al., 2012; Ortiz et al., 2014; Yun et al., 2016). The 11 main phyla gather the vast majority of bacterial sequences, whereas $8.3 \%$ of the sequences shown in Fig. 1a correspond to the rarest phyla, so far hardly documented. Fluctuations in the relative abundance of phyla in the eight cave conditions shown in Appendix S1 (Table S1) are quite substantial, especially when comparing with the stalactites (which represent specific physico-chemical properties; Ortiz et al., 2014; Zepeda Mendoza et al., 2016) of Cave Herrenberg and the floor of Cave Buraco da Sopradeira, located in a semi-arid region (e.g. with a difference of $14 \%$ for Proteobacteria) (Marques et al., 2019). Indeed, different bacterial communities can be evidenced when comparing different caves (Saiz-Jimenez, 2012; Alonso et al., 2019; Zhu et al., 2019) or different conditions within a cave (Schabereiter-Gurtner et al., 2002; Cuezva et al., 2009; Yun et al., 2016; Dhami et al., 2018; Alonso et al., 2018).

The comparison of caves (little or not anthropized) with soil, aquatic, soil, plant and metazoan ecosystems evidences similarities in terms of the main bacterial phyla present (Fig. 1a), which denotes the ecological success and adaptability of these phyla across contrasted environments (Prescott et al., 2018). However, one can also wonder to which extent microorganisms from these types of ecosystems might be connected to cave microbiomes. In this context, the above finding may also be an indication of the occurrence of metapopulations and microbial dissemination into caves, involving soil above caves, water infiltration into caves (for example via rhizosphere channels through the epikarst), and microbial carriage by arthropods or mammals (cited above). Thus, the composition of the bacterial community of karstic caves in limestone, dolomite or marble rock layers (Bakalowicz, 1999; Rusznyák et al., 2012; Alonso et al., 2019; Marques et al., 2019; Wiseschart et al., 2019) may be close to that of calcareous soils (Fig. 1a). Even though caves are inhabited by metazoa, the composition of cave communities is more distant from those of metazoan ecosystems, as caves display a higher abundance of Gemmatimonadetes, Nitrospirae, Acidobacteria, Chloroflexi and Planctomycetes, and a lower abundance of Bacteroidetes (Fig. 1a). This is compatible with the proposed status of Bacteroidetes as bio-indicators of anthropization, whereas the Nitrospirae phylum is associated with limited anthropization (Castro et al., 2002; Herrmann et al., 2015; Alonso et al., 2019).

\subsection{Archaea in caves}

The archaeal community (which is not readily recovered by laboratory cultivation) of non-anthropized caves is mainly composed of Thaumarchaeota and Euryarchaeota on the basis of culture-independent data (Tables 1, 2) (Ortiz et al., 2014; Carmichael et al., 2015; Alonso et al., 2019). The Thaumarchaeota phylum represents more than $70 \%$ of the archaeal sequences in non-anthropized caves (Table 2, Fig. 1b) and literature reported its involvement in $\mathrm{CO}_{2}$ fixation and ammonia oxidation (Ortiz et al., 2014). The Crenarchaeota phylum is also retrieved in caves, representing about $10 \%$ of the archaeal sequences. These Archaea are mostly documented as thermophilic (Bonch-Osmolovskaya et al., 2018) 
A
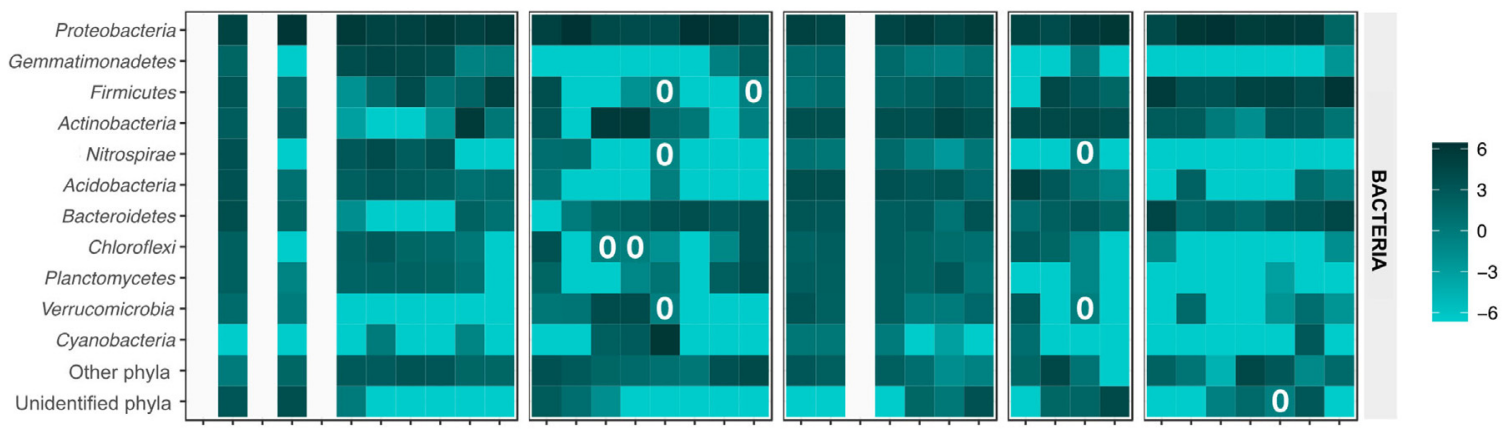

B
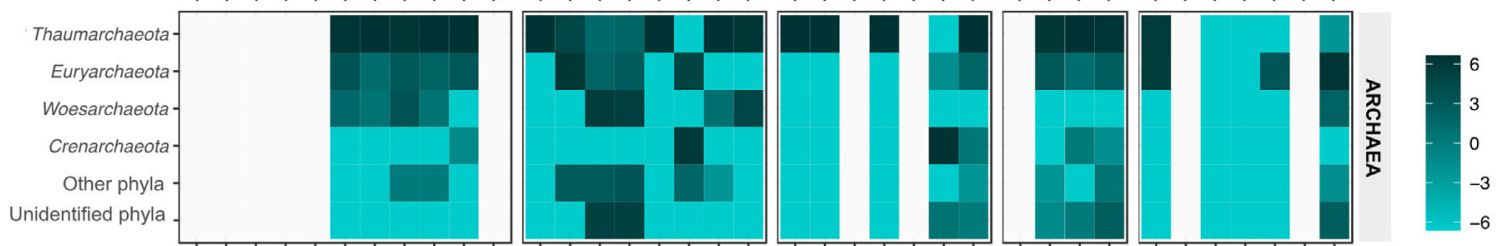

C
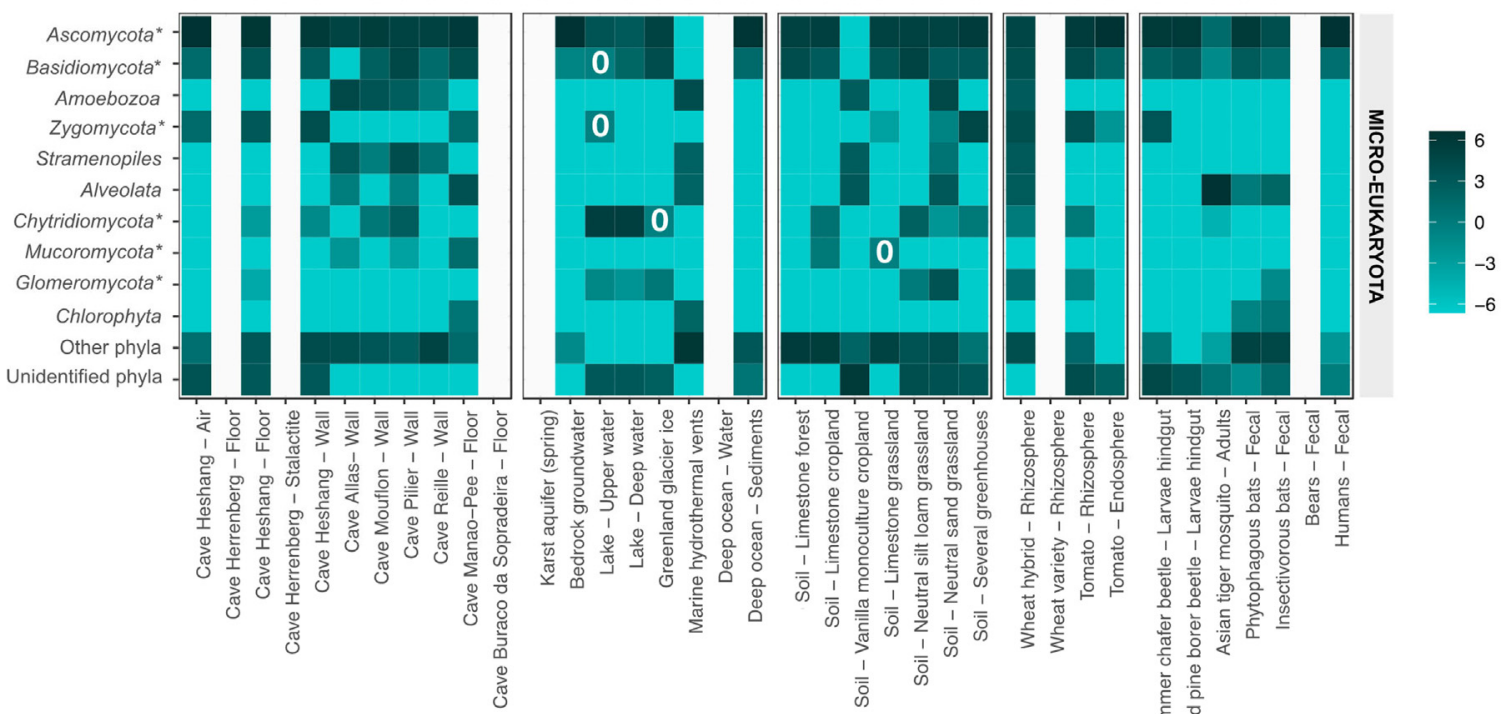

NON-ANTHROPIZED CAVES
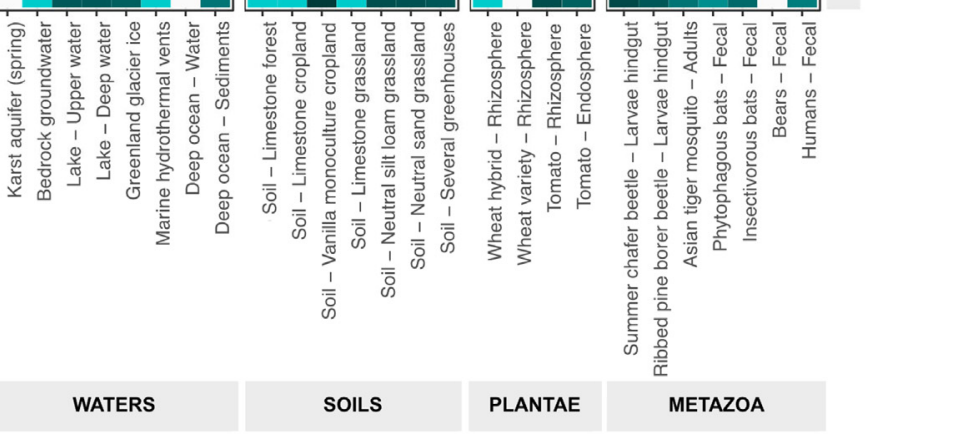

\begin{tabular}{|l|l|l|l|}
\hline NON-ANTHROPIZED CAVES & WATERS & SOILS & PLANTAE \\
\hline
\end{tabular}

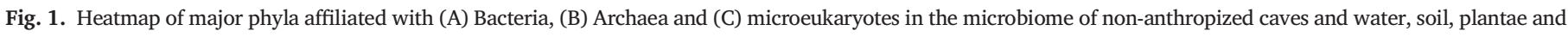

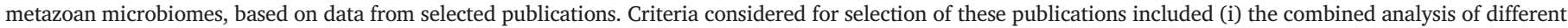

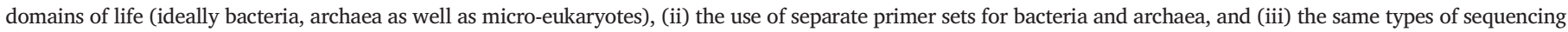

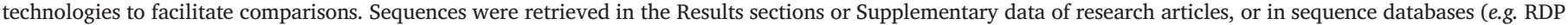

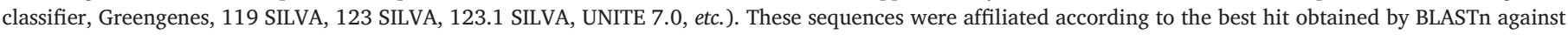

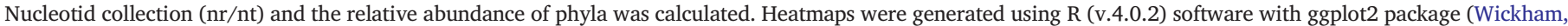

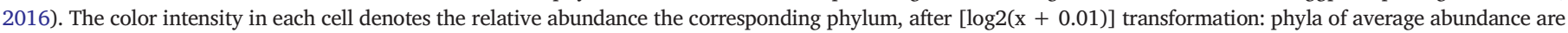

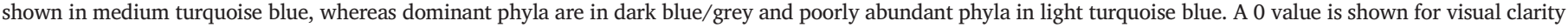

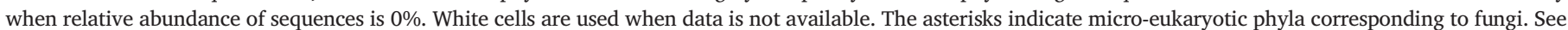

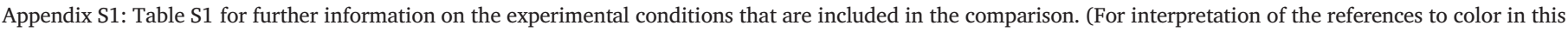
figure legend, the reader is referred to the web version of this article.)

and historically included the mesophilic Crenarchaeota (Schleper et al., 2005; Tomczyk-Żak and Zielenkiewicz, 2016), now recognized as the Thaumarchaeota phylum. The role and activity of the archaeal microorganisms in natural ecosystems is still mysterious, especially in caves (De Mandal et al., 2016; Hershey and Barton, 2018; Alonso et al., 2019). Some differences in archaeal communities can be evidenced when comparing different caves. The Crenarchaeaota were absent from some caves in France (Allas, Mouflon, Pilier, Reille; Alonso et al., 2019), Thailand (Manao-Pee; Wiseschart et al., 2019) and China (Heshang; Yun et al., 2016), but represented the most abundant phylum in Lechuguilla cave (New Mexico) (Northup et al., 2003). This finding is probably due to taxonomic shortcomings in earlier, pioneering work carried out at a time where the Thaumarchaeota were still included within the Crenarchaeota.
Archaeal community composition in caves is distinct from that of the metazoan microbiome shown in Fig. 1b. Indeed, Euryarchaeota are particularly abundant in metazoa (about $30 \%$ of sequences) while representing $<10 \%$ of archaeal sequences in caves. This may be related to the anaerobic conditions prevailing in gut systems, where methane production by Euryarchaeota may take place (Liu and Whitman, 2008). The archaeal community composition of non-anthropized caves resembles that of plants (Fig. 1b), which raises the possibility that some Archaea could originate from the rhizosphere of plants growing above caves, after entry into the caves by water infiltration through the porosity adjacent to the root (microbial dissemination in caves is described above). Such a possibility would need to be assessed experimentally. 
Table 2

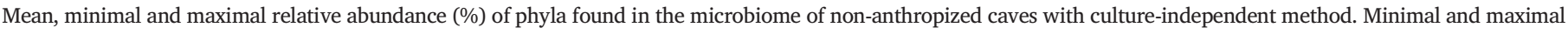
abundances of phyla, number of caves and number of countries are calculated without considering the null values. Hyphens are used when no data is available.

\begin{tabular}{|c|c|c|c|c|}
\hline \multirow[t]{2}{*}{ Phyla } & \multicolumn{2}{|c|}{$\begin{array}{l}\text { Relative abundance } \\
(\%)\end{array}$} & \multirow{2}{*}{$\begin{array}{l}\text { Number of } \\
\text { caves } \\
\text { (where } \\
\text { evidenced) }\end{array}$} & \multirow[t]{2}{*}{ References } \\
\hline & Min & $\overline{\text { Mean }}$ & & \\
\hline
\end{tabular}

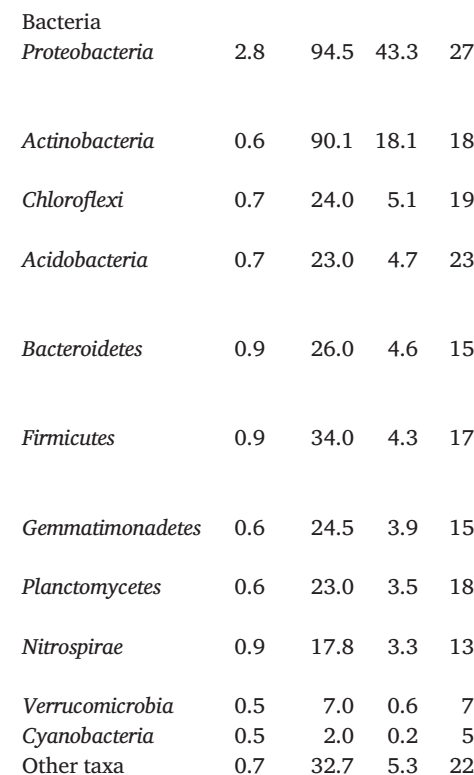

Unidentified taxa $\quad 0.5 \quad 46.0 \quad 3.3 \quad 11$

Archaea

$\begin{array}{lllll}\text { Thaumarchaeota } & 40.0 & 97.0 & 71.2 & 8\end{array}$

$\begin{array}{lllll}\text { Euryarchaeota } & 2.4 & 60.0 & 13.3 \quad 9\end{array}$

$\begin{array}{lcrrr}\text { Crenarchaeota } & 6.0 & 91.0 & 10.8 & 2 \\ \text { Woesearchaeota } & 1.63 & 11.6 & 2.8 & 4 \\ \text { Other taxa } & 0.5 & 1.3 & 0.3 & 3 \\ \text { Unidentified taxa } & 18.0 & 18.0 & 2.0 & 1\end{array}$

Unidentified taxa $\quad 18.0 \quad 18.0 \quad 2.0 \quad 1$

Fungi

Ascomycota $\quad 32.2 \quad 100 \quad 54.1-12$

$\begin{array}{lllll}\text { Zygomycota } & 2.4 & 16.2 & 2.9 & 6\end{array}$

$\begin{array}{llrrr}\text { Chytridiomycota } & 1.2 & 6.4 & 0.6 & 2\end{array}$

$\begin{array}{lllll}\text { Mucoromycota } & 0.1 & 2.4 & 0.2 & 3\end{array}$

Non-fungal microeukaryotic phyla

$\begin{array}{llrll}\text { Amoebozoa } & 0.6 & 22.9 & 3.2 & 5 \\ \text { Stramenopiles } & 0.9 & 17.7 & 3.2 & 6 \\ \text { Alveolata } & 0.7 & 12.5 & 2.3 & 5 \\ \text { Chlorophyta } & 1.4 & 13.0 & 1.7 & 3\end{array}$

Alonso et al., 2019; Barron et al., 2010; Carmichael et al., 2015; D'Auria et al., 2018; De Mandal et al., 2017; De Manda et al., 2016; Epure et al., 2014; Lü et al., 2018; Marques et al., 2019; Zepeda Mendoza et al., 2016; Ortiz et al., 2014; Pasić et al., 2010; Porter et al., 2009; Rusznyák et al., 2012; Wiseschart et al., 2019; Yun et al., 2016 Barron et al., 2010; D'Auria et al., 2018; De Mandal et al., 2017; De Mandal et al., 2016; Marques et al., 2019; Zepeda Mendoza et al., 2016; Ortiz et al., 2014; Pasić et al., 2010; Rusznyák et al., 2012; Wiseschart et al., 2019 Alonso et al., 2019; Barron et al., 2010; Carmichael et al., 2015; D'Auria et al., 2018; De Mandal et al., 2016; Epure et al., 2014; Lü et al., 2018; Marques et al., 2019; Zepeda Mendoza et al., 2016; Ortiz et al., 2014; Pasić et al., 2010 Alonso et al., 2019; Barron et al., 2010; Carmichael et al., 2015; D'Auria et al., 2018; De Mandal et al., 2017; De Mandal et al., 2016; Epure et al., 2014; Lü et al., 2018; Marques et al., 2019; Zepeda Mendoza et al., 2016; Pasić et al., 2010; Porter et al., 2009; Ortiz et al., 2014; Rusznyák et al., 2012; Yun et al., 2016

Alonso et al., 2019; Barron et al., 2010; Carmichael et al., 2015; D'Auria et al., 2018; De Mandal et al., 2017; De Mandal et al., 2016; Lü et al., 2018; Marques et al., 2019; Zepeda Mendoza et al., 2016; Pasić et al., 2010; Rusznyák et al., 2012; Wiseschart et al., 2019; Yun et al., 2016

Alonso et al., 2019; Barron et al., 2010; D'Auria et al., 2018; De Mandal et al., 2017; Epure et al., 2014; Lü et al., 2018; Marques et al., 2019; Zepeda Mendoza et al., 2016; Ortiz et al., 2014; Rusznyák et al., 2012; Wiseschart et al., 2019; Yun et al., 2016

Alonso et al., 2019; Barron et al., 2010; D'Auria et al., 2018; De Mandal et al., 2017; Epure et al., 2014; Lü et al., 2018; Marques et al., 2019; Pasić et al., 2010; Porter et al., 2009; Rusznyák et al., 2012; Wiseschart et al., 2019; Yun et al., 2016 Alonso et al., 2019; Barron et al., 2010; Carmichael et al., 2015; De Mandal et al., 2016; Zepeda Mendoza et al., 2016; Ortiz et al., 2014; Pasić et al., 2010; Porter et al., 2009; Rusznyák et al., 2012; Wiseschart et al., 2019; Yun et al., 2016 Alonso et al., 2019; De Mandal et al., 2017;Epure et al., 2014; Lü et al., 2018; Ortiz et al., 2014; Pasić et al., 2010; Rusznyák et al., 2012

Carmichael et al., 2015; Lü et al., 2018; Pasić et al., 2010; Rusznyák et al., 2012; Yun et al., 2016

Alonso et al., 2019; Lü et al., 2018; Zepeda Mendoza et al., 2016; Ortiz et al., 2014

Alonso et al., 2019; Barron et al., 2010; Carmichael et al., 2015; D'Auria et al., 2018; De Mandal et al., 2017; De Mandal et al., 2016; Epure et al., 2014; Lü et al., 2018; Marques et al., 2019; Zepeda Mendoza et al., 2016; Ortiz et al., 2014; Porter et al., 2009; Rusznyák et al., 2012; Wiseschart et al., 2019

Alonso et al., 2019; Barron et al., 2010; De Mandal et al., 2016; Zepeda Mendoza et al., 2016; Rusznyák et al., 2012

Alonso et al., 2019; Carmichael et al., 2015; Ortiz et al., 2014; Wiseschart et al., 2019; Yun et al., 2016

Alonso et al., 2019; Carmichael et al., 2015; Northup et al., 2003; Vaughan et al., 2011; Wiseschart et al., 2019; Yun et al., 2016

Northup et al., 2003; Ortiz et al., 2014

Alonso et al., 2019

Alonso et al., 2019; Ortiz et al., 2014; Yun et al., 2016

Alonso et al., 2019; Ortiz et al., 2014

Alonso et al., 2019; Epure et al., 2014; Man et al., 2018; Zepeda Mendoza et al., 2016; Rusznyák et al., 2012; Wiseschart et al., 2019; Zorn, 2014

Alonso et al., 2019; Man et al., 2018; Zepeda Mendoza et al., 2016; Rusznyák et al., 2012; Wiseschart et al., 2019; Zorn, 2014

Alonso et al., 2019; Man et al., 2018; Rusznyák et al., 2012; Zorn, 2014

Alonso et al., 2019

Alonso et al., 2019; Wiseschart et al., 2019

Alonso et al., 2019; Ortiz et al., 2014

Alonso et al., 2019; Zepeda Mendoza et al., 2016; Ortiz et al., 2014

Alonso et al., 2019; Zepeda Mendoza et al., 2016; Ortiz et al., 2014; Wiseschart et al., 2019

Zepeda Mendoza et al., 2016; Ortiz et al., 2014; Wiseschart et al., 2019

Other situations with microeukaryotes

Other taxa $\quad 2.1 \quad 48.0-12.11$

Alonso et al., 2019; Man et al., 2018; Zepeda Mendoza et al., 2016; Rusznyák et al., 2012; Wiseschart et al., 2019; Zorn,

2014

Unidentified taxa $\quad \begin{array}{llll}5.0 & 21.0 & 6.2 & 7\end{array}$

Man et al., 2018; Zepeda Mendoza et al., 2016; Zorn, 2014

\subsection{Fungi and other microeukaryotes in caves}

The microeukaryotic community in non-anthropized caves is predominantly composed by the fungal phylum Ascomycota (about half the available sequences) (Zepeda Mendoza et al., 2016; Man et al., 2018; Alonso et al., 2019; Wiseschart et al., 2019), a highly diverse phylum involved in the decay of organic substrates and in intimate relations with animals, plants and other Fungi (Northup et al., 2003). Within Ascomycota, Fusarium spp. were the only species documented by both cultivation and molecular methods in Doña Trinidad Cave (Stomeo et al., 2009). The next prevalent phylum is the Basidiomycota (important for degradation of polymers e.g. cellulose) (10\%), which is less adapted to oligotrophic conditions compared to Ascomycota (Vanderwolf et al., 2013) (Tables 1, 2, Fig. 1c). Different fungal communities can be found in different caves (Alonso et al., 2019; Zhang and Cai, 2019), or when comparing different conditions and substrates within a cave (Man et al., 2018; Zhang and Cai, 2019). For example, the fungal phylum Zygomycota represented about 16\% of all microeukaryotes in weathered rocks at Heshang Cave (China) (Man et al., 2018) vs only $2 \%$ on the floor of Manao-Pee Cave (Thailand) (Wiseschart et al., 2019). However, non-fungal taxa present in the cave microeukaryotic community have rarely been considered, and their ecological importance remains largely undocumented. To date, there have been few studies of protists in non-anthropized caves 
(Zepeda Mendoza et al., 2016). Alonso et al. (2019) described protist taxa in a larger investigation of the microeukaryotic community in four pristine caves in France (Allas, Mouflon, Pilier and Reille), where fungal taxa were more abundant than protists.

The microeukaryotic community of non-anthropized caves is largely similar to those in the other ecosystems compared (Fig. 1c). The Ascomycota are prevalent in caves, but they are also prevalent in soils worldwide (Schoch et al., 2009). The non-fungal groups Amoebozoa and Alveolata are often found in soil and water, respectively (Antranikian et al., 2017; Sauvadet et al., 2010; Xiong et al., 2018), a feature shared by karst environments which are also hydro-geological systems, with a well-developed underground drainage network (Bakalowicz, 1999; Engel, 2010).

\subsection{Endemic features of the cave microbiome}

Overall, the main microbial phyla prevalent in pristine caves are similar to those evidenced in other ecosystems, especially water and soil. However, the situation is not as clear when considering lower taxonomic levels (SaizJimenez, 2012), and many microorganisms typical of caves are thought to be limited to underground environments (Engel, 2019). For instance, evidence was found for a new cave-adapted methane-oxidizing bacterial species from the genus Methylomonas (Kumaresan et al., 2018). Regarding fungi, many species have only been reported in caves (Zhang et al., 2018), such as the Ochroconis species O. anellii, O. anomala and O. lascauxensis (MartinSanchez et al., 2012b; Giraldo et al., 2014; Samerpitak et al., 2015), the Mortierella species M. rhinolophicola, M. multispora and M. yunnanensis, and Neocosmospora pallidimors (Karunarathna et al., 2020). However, the absence of these species outside caves remains to be clarified. The bat pathogen Pseudogymnoascus destructans is believed to have evolved from a caveendemic Pseudogymnoascus species (Hershey and Barton, 2018). Additional endemic taxa might be identified with a more detailed appraisal of the rare cave biosphere (Hershey and Barton, 2018). At intra-species levels, the descriptions of cave-adapted genotypes (or strains) in fluorescent Pseudomonas (Hershey and Barton, 2018; Turrini et al., 2020) and Streptomyces lavendulae or related species (Gosse et al., 2019) point towards endemic distributions. UV resistance is thought to be counter-selected in troglobitic bacteria (Snider et al., 2009).

Even though microorganisms from other environments can be transferred into caves, where they may represent environmental contaminants rather than endemic cave inhabitants (Vanderwolf et al., 2013; Davis et al., 2020; Morse et al., 2021), they are confronted to strong Darwinian selection once in caves (Hershey and Barton, 2018). Therefore, microbial communities in cave may display taxa common to those from other environments, but present at very different population levels. Thus, higher abundances in caves have been highlighted for e.g. the bacterial phyla Acidobacteria and Nitrospira, the class Deltaproteobacteria and the Betaproteobacteria families Oxalobacteraceae, Methylophilaceae and Comamonadaceae (SchabereiterGurtner et al., 2002; Ivanova et al., 2013), as well as the fungal class of Sordariomycetes (50-60\% of sequences in caves $v s<10 \%$ in soils or metazoa; Alonso et al., 2018; Ziganshina et al., 2018; Zheng et al., 2019) or the fungal genus Alternaria well present underground (Man et al., 2018). On this basis, data point mostly to the occurrence of specialized microbial communities endemic to caves (Ivanova et al., 2013; Hershey and Barton, 2018; Engel, 2019; Davis et al., 2020; Morse et al., 2021) rather than cave-endemic microbial taxa per se, but further microbial diversity descriptions are needed for a more robust appraisal.

\section{Tourist Paleolithic caves and effects of contemporary anthropization on microorganisms}

\subsection{Tourist Paleolithic caves}

Paleolithic caves represent a very particular kind of underground systems. They are caves harboring archaeological artwork, which is thought to date from the end of the Middle Paleolithic (the Middle Paleolithic lasted from 300,000-200,000 to 50,000-30,000 years Before Present (BP)) and especially the Upper Paleolithic (50,000-30,000 to 12,000-10,000 years BP) (Mohen and Taborin, 2009). In these caves, parietal artwork includes engravings, drawings, paintings and sometimes carvings, which are present on the walls and ceiling of the cavities.

Caves that were subsequently used for artwork started to form long (millions years) before humans started their exploration. Cave formation took place during the Cretaceous (145-66 million years BP) or the Neogene (23-2.6 million years BP), as illustrated in Fig. 2 for the Large Cave (Grande Grotte) of Arcy-sur-Cure (France), Chauvet Cave (France) and Cave of Altamira (Spain). Perhaps the time of formation of these caves, their geologic history and ancient biological events (e.g. their mode of frequentation by animals in the distant past) are important factors that would need to be considered to understand their legacy for the ecology of current microorganisms and microbial adaptation to pristine cave conditions.

During the second half of the Lower Paleolithic (the Lower Paleolithic lasted from around 3 million years to 300,000 years BP), prehistoric men occupied caves, mainly at their entrance (Cauche, 2009) as they provided a protected environment. In certain caves, human occupation extended over 200,000 years, as in the caves of Arcy-sur-Cure (Fig. 2) (Baffier and Girard, 1997). Hundreds of caves have been decorated. Human traces left in these caves (e.g. bones, objects and parietal art) can be analyzed using various techniques $\left({ }^{14} \mathrm{C}\right.$ dating, thermoluminescence, optically stimulated luminescence, uranium-thorium radiometry, etc.) (Sauvet, 2015), allowing to date the artwork of the caves of El Castillo (Spain), Altamira (Spain), Chauvet (France), Tito Bustillo (Spain), Lascaux (France) and Magura (Bulgaria) at about 41,000, 36,000-13,000, 33,000, 20,000, 18,000 and 10,000 years BP, respectively (Glory, 1964; Hoyos et al., 1998; Valladas et al., 2005; Pike et al., 2012; Biot, 2013; Ivanova et al., 2013). Landslides blocking the entrance terminated human presence in certain caves. Chauvet Cave was frequented by humans during the Aurignacian $(43,000-$ 29,000 years BP) until a first landslide, and then during the Gravettian $(33,000-21,000$ years BP) till a second landslide dated 13,000 years BP caused the closure of the cave, which was rediscovered in 1994 (Le Guillou, 2005).

The history of human presence after the Paleolithic is poorly documented. During antiquity, the Romans and the Greeks used certain caves for thermalism, made pilgrimages and practiced religious and funeral activities in caves (Verde, 2000). In the Middle Ages, the caves served as refuges during wars or epidemics (Cigna et al., 2013). The earliest descriptions of caves date back to Roman times and later the Renaissance (Biot, 2006; Cigna, 1993; Cigna et al., 2013; Cigna, 2016). The first tourist visits to a cave, i.e. for the sake of pleasure and recreation, might have taken place 3100 years BP in Turkey (Cigna et al., 2013). Tourism as we know it nowadays, i.e. with the commercial provision of services, started in Vilenica Cave (Slovenia) at the beginning of the 17th century (Cigna et al., 2013). Thus, natural caves have been opened to tourists for 400 years (Pfendler et al., 2018). A show cave (also called tourist cave or public cave) is a cave that has been made accessible to the public for guided visits (Cigna et al., 2013; Cigna, 2016; Cigna and Burri, 2000). In France, 80 underground cavities have been developed as show caves for touristic purposes from 1919 to 2005 (Biot, 2006, 2013). Nowadays, more than 800 caves worldwide are open to the public (Fig. 3) and 250 million tourists visit them each year (Cigna, 2016; Pfendler et al., 2018). Caves attract tourist attention for concretions (stalactites and stalagmites), underground lakes and/or prehistoric artwork. The majority of decorated caves dating from the Paleolithic are found in western Europe (especially France and Spain) (Fig. 3). Some of them are now classified as United Nations Educational, Scientific and Cultural Organisation (UNESCO) World Heritage Sites, such as Lascaux (in 1979), Altamira (1985) and Chauvet (2014).

\subsection{Anthropization of Paleolithic caves related to tourism}

The opening of Paleolithic caves for tourism can modify strongly environmental conditions prevailing in these underground systems. The resulting alterations that were observed can be problematic for preservation of artwork, and this forced many caves to close for preservation purposes 
GREAT CAVE OF ARCY-SUR-CURE

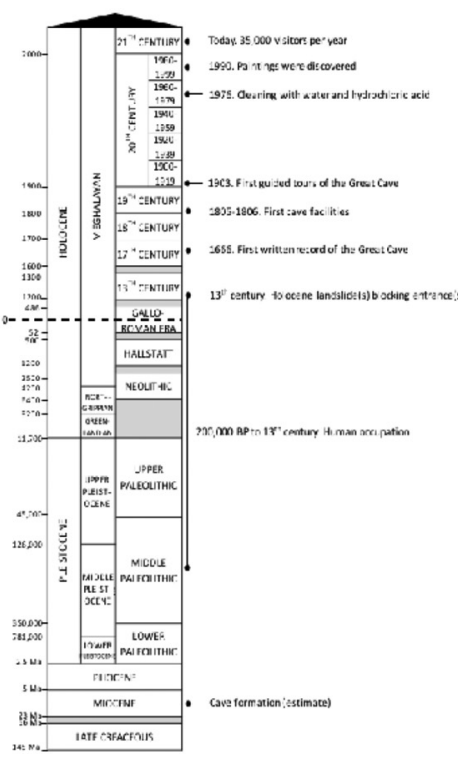

LASCAUX CAVE

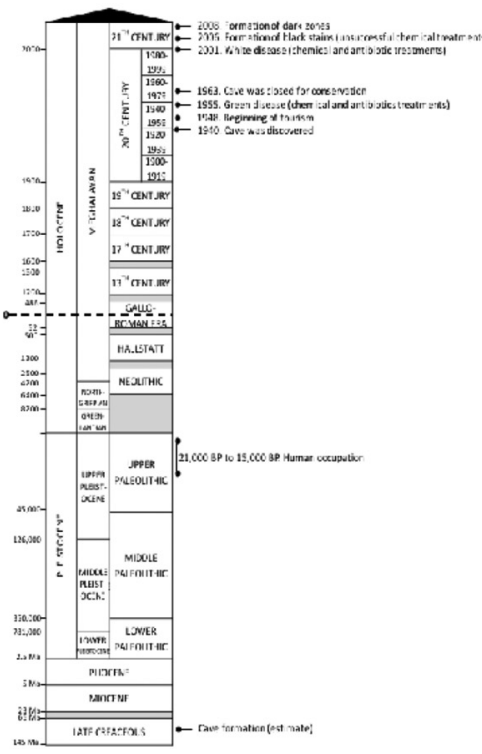

CAVE OF MLTAMIRA

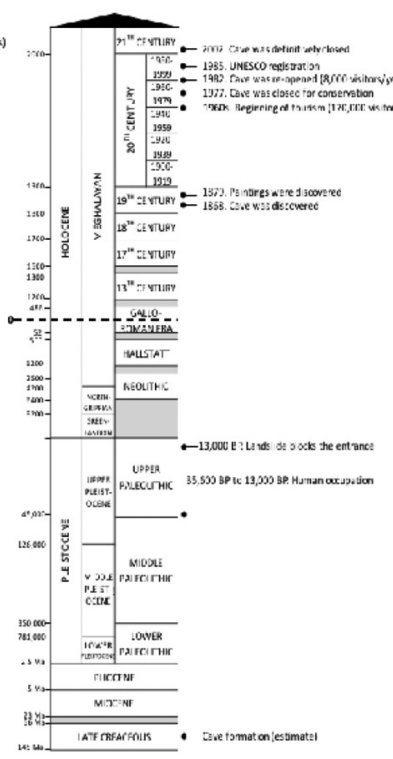

CHAUVET CAVE

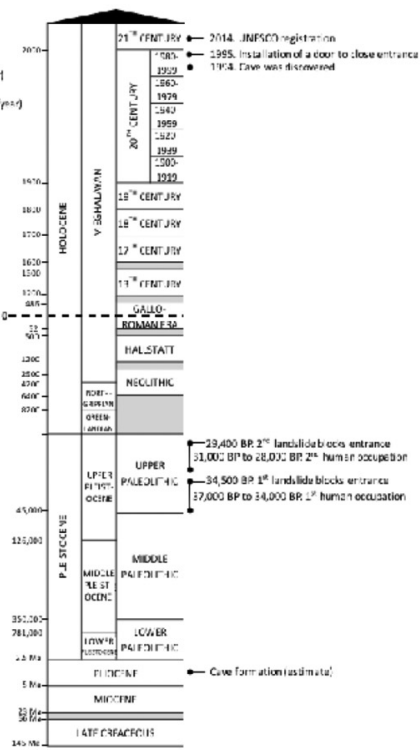

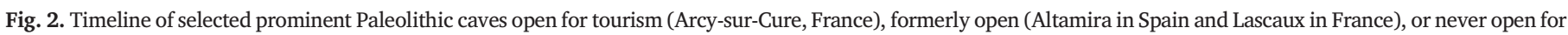
tourist visits (Chauvet, France). Key geological processes, human occupations and modern events are indicated.

(Fig. 3). This is in particular the case of the emblematic caves of Lascaux (more than 100,000 visitors per year in the early 1960s, closed in 1963) and Altamira (more than 170,000 visitors per year in the 1960s, closed in 2002) (Figs. 2 and 3). Many Paleolithic caves are closed to the public, yet $45 \%$ of them are still open for visits (Fig. 3, Appendix S2: Table S2) (Ministère de la Culture et de la Communication, 2020).

In certain cases, cave disturbance started even earlier than the implementation of tourism, i.e. with the initial opening of caves so far largely disconnected from the outside environment, sometimes following geologic events such as landslides, etc. This can immediately cause major changes in the cave, especially of climatic conditions (Bastian et al., 2010). In tourist caves, some of the facilities to accommodate visitors were developed as early as in the 1630s for Vilenica Cave (Slovenia) (Cigna et al., 2013) and the 1800s for the Large Cave of Arcy-sur-Cure (France) (Baffier and Girard, 1997; Cigna et al., 2013). The soil surfaces of King Salomons Cave (in Tasmania) and Lascaux Cave (in South-West France) were also excavated to facilitate access (Russell and MacLean, 2008). Often, stairs and artificial light were installed (Dupont et al., 2007), and sometimes also concrete pathways (Russell and MacLean, 2008), which can significantly impact environmental conditions within caves. In Lascaux Cave, machinery was installed in 1958 to limit water evaporation and condensation (Brunet et al., 1987; Bastian et al., 2010), and equipment for climatic regulation of the cave was replaced and modified in 1966 and in the early 2000 (Dupont et al., 2007), prior to its phasing out in 2015. The visitors themselves can

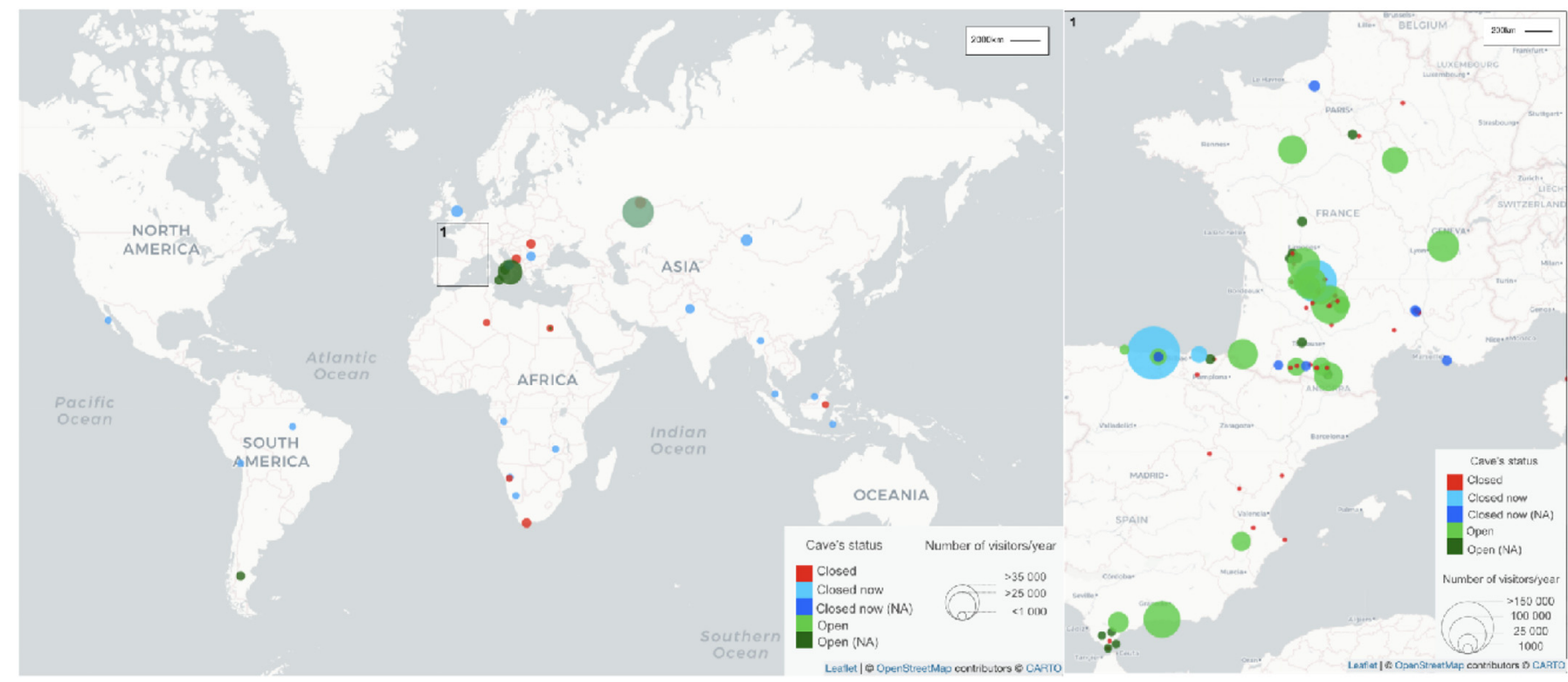

Fig. 3. Geographic location of 125 selected Paleolithic caves, with (i) their touristic status i.e. never open ('Closed' / red circles), now closed after having been open for visits ('Closed now' / blue circles or 'Closed now (NA)' / dark blue circles), open for tourism ('Open' / green circles or 'Open (NA)' / dark green circles), (ii) the number of visitors per year (including for previously-open caves before they became closed; 'NA' means that data is not available and the corresponding circles were arbitrarily set to minimum size). More information on these caves is given in Appendix S2: Table S2. (For interpretation of the references to color in this figure legend, the reader is referred to the web version of this article.) 
cause strong changes in cave microclimate, with an increase in temperature, $\mathrm{CO}_{2}$ concentrations (which can affect the chemical equilibrium of calcite) and water vapor levels (Cañveras et al., 2001; Russell and MacLean, 2008; Bastian et al., 2009b; Diaz-Herraiz et al., 2014). In Tito Bustillo and Altamira caves, water vapor exhaled by visitors resulted in condensed aerosols on cave surfaces (Cañveras et al., 2001; Espino del Castillo et al., 2018). Therefore, these visitors can also bring organic matter and dust from the outside on their shoes, or drop strands of hair and flakes of skin (Cañveras et al., 2001). A tourist that became sick during his visit to Castañar de Ibor Cave (Spain) raised organic carbon content of the cave sediment from $0.10 \%$ to $0.28 \%$ where he vomited (Jurado et al., 2010). Changes in temperature (often increases) were evidenced in several frequented Paleolithic caves, e.g. $\pm 0.20{ }^{\circ} \mathrm{C}$ in Tito Bustillo Cave, \pm $0.25^{\circ} \mathrm{C}$ in Altamira Cave (Cañveras et al., 2001) and $+1.50{ }^{\circ} \mathrm{C}$ in Lascaux Cave (Dupont et al., 2007) compared with original temperatures. As a result, ecological perturbation undergone by these show caves materialized by multiple changes in environmental features, which was likely to impact the structure and functioning of microbial communities.

The introduction of allochthonous nutrients in tourist caves may favor the growth of heterotrophic bacteria, the development of new microbial populations, and/or the inhibition of indigenous populations (Groth et al., 1999; Bastian et al., 2009a; Bastian and Alabouvette, 2009; Espino del Castillo et al., 2018; Wasti and Seelan, 2019). The microbial diversity of anthropized and non-anthropized Paleolithic caves has been investigated for the three domains of life using new generation sequencing techniques (Alonso et al., 2019). This work showed a unique microbiota for the most anthropized cave (Lascaux Cave), as well as a higher proportion of Bacteroidetes (6.0\% vs $0.1 \%$ ) and the absence of Euryarchaeota and Woesearchaeota in anthropized caves compared with pristine caves (Fig. 4). Indeed, Bacteroidetes have been proposed as bioindicators of human disturbance in tourist caves (Mulec et al., 2017; Espino del Castillo et al., 2018). Certain visited caves may even represent a reservoir of pathogens (reviewed by Saiz-Jimenez, 2012) e.g. Staphylococcus and Escherichia coli (Espino del Castillo et al., 2018; Dhawi, 2020), likely linked to human inputs. Specific microbiota modifications due to anthropization may be expected at community level, with changes in species richness or community structure (Ikner et al., 2007; Ager et al., 2010; Alonso et al., 2019). In South-West France, cave anthropization resulted in lower species richness and altered structure of prokaryotic communities on the wall of the caves (Alonso et al., 2019) (Fig. 4). Impacts were stronger on the prokaryotic communities rather than on eukaryotic communities, irrespective of cave physicochemical properties (Ikner et al., 2007; Alonso et al., 2019). However, fungal diversity might also be impacted, with higher tourism level correlating with lower fungal species richness (Joshi and Chettri, 2019; Wasti and Seelan, 2019). Tourism impact on microorganisms might be indirect, e.g. mediated by anthropization effects on cave fauna. In the Grotta di Catellana (Italy), indigenous species of beetles initially observed near the tourist trails were restricted to more remote parts of the cave after a few years of exploitation, while the section visited became dominated by mice feeding on visitors waste (Cigna, 1993). Non-native vertebrates or invertebrates in caves might act as reservoirs of entomopathogenic microorganisms, such as Mucor circinelloides found in rodent droppings (Jurado et al., 2010) or Chrysosporium, Gliocladium and Verticillium isolated from the corpses of crickets (Bastian et al., 2009b).

Overall, the assessment of anthropization effects has focused so far on Bacteria and Fungi, and therefore these effects remain incompletely documented. In addition, a wider range of geological and climatic settings should be considered in these assessments, including caves that have undergone different levels or types of anthropization, to establish the genericity of findings.

\section{Microbial alteration of rock surfaces in tourist Paleolithic caves}

\subsection{Microbial alteration processes in Paleolithic caves}

Cave biota imbalance following anthropization may cause microbial alteration of rock surfaces (Table 3), which can entail (i) excessive growth of
A
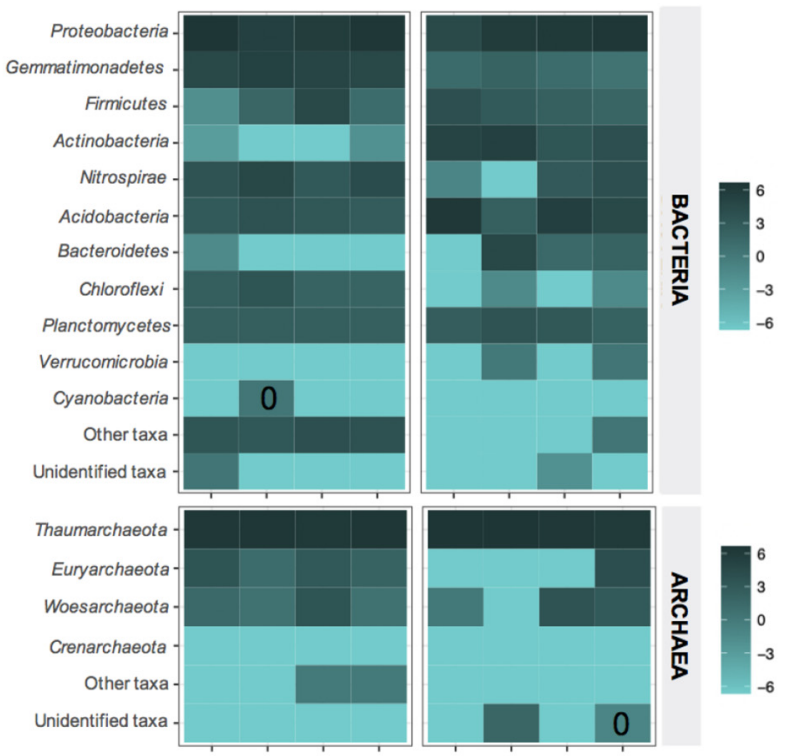

B
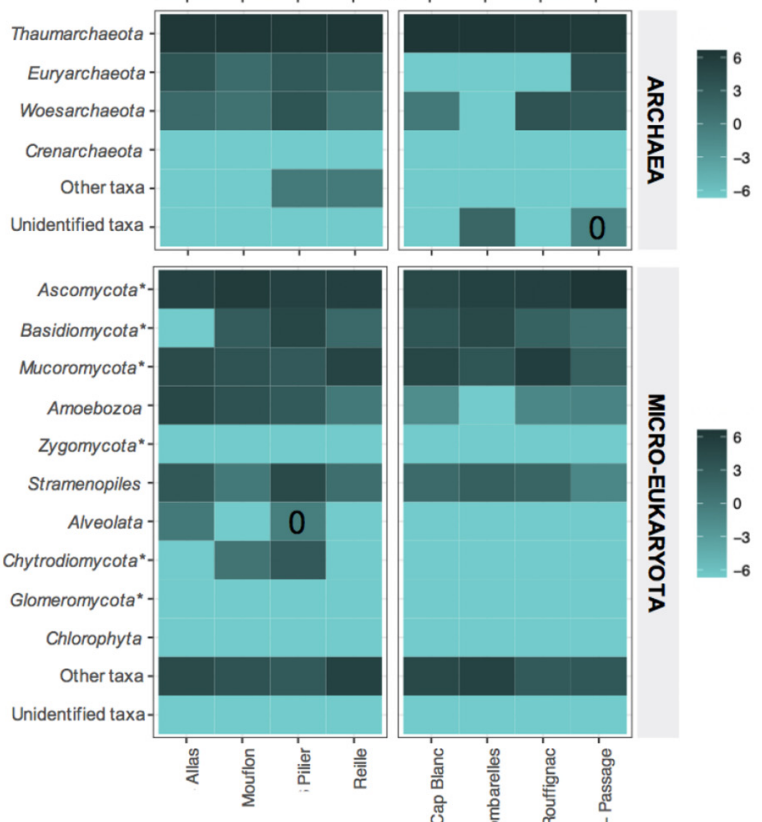

C

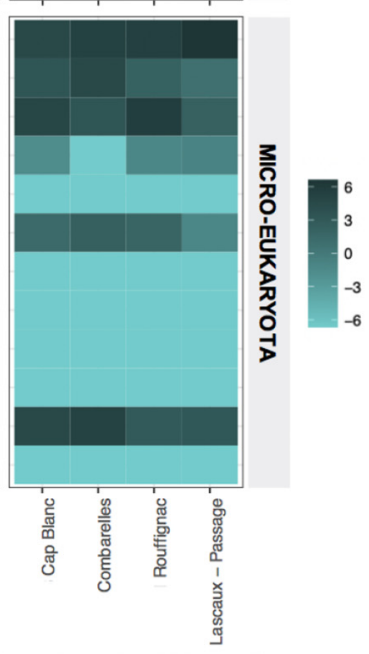

PRISTINE CAVES ANTHROPIZED CAVES

Fig. 4. Microbiome of Paleolithic caves open (or previously open) for tourism $v s$ pristine caves, based on selected data in Alonso et al. (2019). Heatmaps are shown for major phyla affiliated with (A) Bacteria, (B) Archaea and (C) microeukaryotes. These sequences were affiliated according to the best hit obtained by BLASTn and the abundance of phyla was calculated. Heatmaps were generated using R (v.4.0.2) software with ggplot2 package (Wickham, 2016). The color intensity in each cell denotes the relative abundance the corresponding phylum, after $[\log 2(\mathrm{x}+0.01)]$ transformation: phyla of average abundance are shown in medium turquoise blue, whereas dominant phyla are in dark blue/grey and poorly-abundant phyla in light turquoise blue. A 0 value is shown for visual clarity when relative abundance of sequences is $0 \%$. White cells are used when data is not available. The asterisks indicate micro-eukaryotic phyla corresponding to fungi. See Appendix S3: Table S3 for further information on the experimental conditions that are included in the comparison. (For interpretation of the references to color in this figure legend, the reader is referred to the web version of this article.)

microorganisms (resulting in colored stains), (ii) chemical reactions carried out by microorganisms or facilitated by microbial constituents, and/or (iii) mechanical alteration, often due to the rupture of rock substrates by Fungi (Cañveras et al., 2001; Barton and Jurado, 2007; Cuezva et al., 2012; Stupar et al., 2014; Pfendler et al., 2018).

Excessive growth of Archaea, Bacteria and microeukaryotes is one of the main factor responsible for the degradations observed in caves (Cañveras et al., 2001; Wang et al., 2010; Mihajlovski et al., 2019). This is well documented for 'lampenflora', an invasive and opportunistic community due to 
Table 3

Selected cases of microbial alterations documented in Paleolithic caves.

\begin{tabular}{|c|c|c|c|c|}
\hline Alteration & Color & Cave & Microbial process proposed & Reference \\
\hline Biofilm & Green & Many caves worldwide & Growth of algae and other microorganisms & $\begin{array}{l}\text { Lefévre 1974; Baquenado Estévez } \\
\text { et al. } 2019\end{array}$ \\
\hline \multirow[t]{2}{*}{ Calcite veil } & Translucent & Caves of Arcy-sur-Cure ${ }^{1}$ & $\begin{array}{l}\text { Precipitation of calcium carbonate which involved bacteria (Pseudomonas, } \\
\text { Bacillus and Myxococcus) }\end{array}$ & Chalmin et al. 2007 \\
\hline & Opaque & $\begin{array}{l}\text { Caves of Arcy-sur-Cure, Lascaux } \\
\text { Cave }^{1}\end{array}$ & $\begin{array}{l}\text { Precipitation of calcium carbonate which involved bacteria (Pseudomonas, } \\
\text { Bacillus and Myxococcus) }\end{array}$ & $\begin{array}{l}\text { Chalmin et al. 2007; Martin-Sanchez } \\
\text { et al. } 2015\end{array}$ \\
\hline Efflorescence & White & Sorcerer's Cave ${ }^{1}$ & Gypsum precipitation & Lepinay et al. 2018 \\
\hline \multirow[t]{5}{*}{ Stains } & White & $\begin{array}{l}\text { Cave of Altamira }{ }^{2} \text {, Lascaux } \\
\text { Cave }\end{array}$ & Growth of white fungi and perhaps also bacteria (Proteobacteria, Acidobacteria) & $\begin{array}{l}\text { Bastian et al. 2010; Portillo et al. } \\
\text { 2008, } 2009\end{array}$ \\
\hline & Black & Lascaux Cave, Cave of Bats ${ }^{2}$ & Growth of black fungi & $\begin{array}{l}\text { Bastian et al. 2010; Urzi et al. 2010; } \\
\text { De Leo et al. } 2012\end{array}$ \\
\hline & Yellow & $\begin{array}{l}\text { Cave of Altamira, Pajsarjeva } \\
\text { Jama Cave }^{3}\end{array}$ & Growth of bacteria (Xanthomonodales) & Portillo et al. 2008; Pasić et al., 2010 \\
\hline & Grey & $\begin{array}{l}\text { Cave of Altamira, Pajsarjeva } \\
\text { Jama Cave }\end{array}$ & Growth of bacteria (Thauera) & Portillo et al. 2008; Pasić et al., 2010 \\
\hline & Red & Cave of Bats & Unknown & Urzì et al., 2010 \\
\hline $\begin{array}{l}\text { Microbial } \\
\text { structure }\end{array}$ & Blue-black & Driny Cave ${ }^{4}$ & Growth of Penicillium glandicola & Ogórek et al. 2016 \\
\hline
\end{tabular}

Caves are located in France ${ }^{1}$, Spain $^{2}$, Slovenia ${ }^{3}$, Slovakia ${ }^{4}$.

the artificial lighting implemented in caves, which forms green stains in the vicinity of light systems (Saiz-Jimenez, 2012). Lampenflora consist mainly of Cyanobacteria and Chrysophyta (Stramenopiles), as well as Plantae members especially algae (Chlorophyta) (Bastian et al., 2010; Baquedano Estévez et al., 2019). Lampenflora are common in tourist Paleolithic caves, and in Lascaux in the 1960s they were termed the green disease considering their significant development (Lefèvre, 1974; Bastian and Alabouvette, 2009; Bastian et al., 2010; Baquedano Estévez et al., 2019). At later times in Lascaux Cave, other cases of microbial outgrowth occurred on cave surfaces and resulted in the formation of problematic stains (Mauriac, 2014). Early 2001, spectacular development of the white fungus Fusarium solani took place, first in the entrance zone and later in most rooms of the cave (Bastian et al., 2009b; Bastian et al., 2010). The resulting white stains corresponded to the fungal mycelium itself. Towards the end of 2001 and especially a few years later, black stains also appeared, in relation to the development of black Fungi (Bastian et al., 2009b; Bastian et al., 2010; Alonso et al., 2018). This time, the stains corresponded to the presence of back pigments (melanins) synthesized by the fungi (De la Rosa et al., 2017) rather than the mycelia themselves. Several black Fungi were identified from stains, including Ochroconis lascauxensis (Sympoventuriaceae family), Acremonium nepalense (Hypocreaceae family) and Exophiala castellanii (Herpotrichiellaceae family) (Martin-Sanchez et al., 2012b; Alonso et al., 2018). Microbial diversity was not markedly different inside $v s$ outside black stains, and black Fungi were also present outside of stains, highlighting the potential for new black stain formation (Alonso et al., 2018). Black Fungi from the Hypocreaceae (i.e. Acremonium species) and Teratosphaeriaceae families have been evidenced in comparable settings corresponding respectively to tumulus walls in Japan (Kiyuna et al., 2011) and a cave with medieval wall paintings (Zucconi et al., 2012), whereas Streptomyces isolates from ancient Egyptian paintings could produce black pigments (Abdel-Haliem et al., 2013). Surface alteration resulting from microbial outgrowth has also been documented in Altamira Cave, where yellow and grey stains that formed on walls displayed microbial specificities (Saiz-Jimenez, 2012). For example, Xanthomonadales (Gammaproteobacteria) were only found in yellow stains, whereas the prevalence of Thauera (Betaproteobacteria) was higher in grey stains than in yellow stains (Cañveras et al., 2001; Portillo et al., 2008). In the Sorcerer's cave (Vézère Valley, France), natural crystallization of gypsum salt following capillarity transport covered prehistoric artwork (Lepinay et al., 2018). However, these saline efflorescences promoted the proliferation of halotolerant and/or halophilic microorganisms, with the formation of microbial pigments that led to surface coloration (Lepinay et al., 2018; Mihajlovski et al., 2019).

In addition, cave wall alteration may also entail chemical reactions catalyzed by microorganisms such as Bacteria (especially from the Actinobacteria), which result in biotransformations of mineral surfaces in caves (Diaz-Herraiz et al., 2014; Tomczyk-Żak and Zielenkiewicz, 2016). This possibility is particularly documented for calcium carbonate, with microbial dissolution of limestone as well as precipitation leading to the formation of a calcite veil, but it may also concern other mineral constituents. The dissolution of rocks by Bacteria and Fungi occurs through the release of organic and mineral acids (Northup and Lavoie, 2001), e.g. sulfuric acid produced from bacterial oxidation of iron, sulfur, or manganese as documented in Lechuguilla and Spider caves in New Mexico. This dissolution could also be done by secretion of extracellular enzymes, but this has not yet been demonstrated to date (Sand, 1997; Northup and Lavoie, 2001). Limestone dissolution can also implicate (micro)organisms already acting by causing stain formation, as documented for lampenflora, in relation to the production of carbonic acid during respiration (Baquedano Estévez et al., 2019). Precipitation processes can be passive, when a specific cellular activity solely directs the spontaneous nucleation, growth, morphology and final location of a mineral, or active when bacterial enzymes are involved or the metabolic activity of microorganisms changes the $\mathrm{pH}$ or modulates redox transformations in the microenvironment (Northup and Lavoie, 2001; Barton and Jurado, 2007; Lepinay et al., 2018). In the large cave of Arcy-sur-Cure, two types of biogenic calcites (translucent and opaque) were obstructing artwork on cave walls, which involved bacteria thought to belong to Pseudomonas fluorescens, Bacillus megaterium or Myxococcus xanthus (Chalmin et al., 2007). Whether microorganisms were also involved in the formation of the white calcite veil (termed white disease) that prompted closure of Lascaux Cave is not clear.

Finally, cave wall alteration by microorganisms can also involve active mechanical processes as certain microorganisms, during their growth, induce a physical pressure capable of breaking up mineral particles (Lian et al., 2011). This is particularly the case of Fungi, whose mycelium penetrates, envelops and cracks surface particles (Sterflinger, 1998; Kumar and Kumar, 1999).

Different types of cave alterations have been investigated, but the comparison with neighboring, unaltered rock surface is often lacking (Fig. 5). In addition, when culture-dependent approaches were used, Archaea could not be recovered. In comparison with unaltered surfaces, black stains in Lascaux did not display differences in the composition of bacterial and fungal phyla, but differences were found at the genus level. In particular, the fungal genera Ochroconis and Exophiala showed a higher abundance in stains (respectively $26 \%$ and $37 \%$, vs $1.1 \%$ and $0.2 \%$ of sequences outside the stains) and the bacterial genus Pseudomonas a lower abundance (0.01-0.11\%, vs 34-63\% of sequences outside stains) (Alonso, 2018).

Overall, considerable information is available on microbial alteration that may take place in tourist Paleolithic caves. However, the role of 


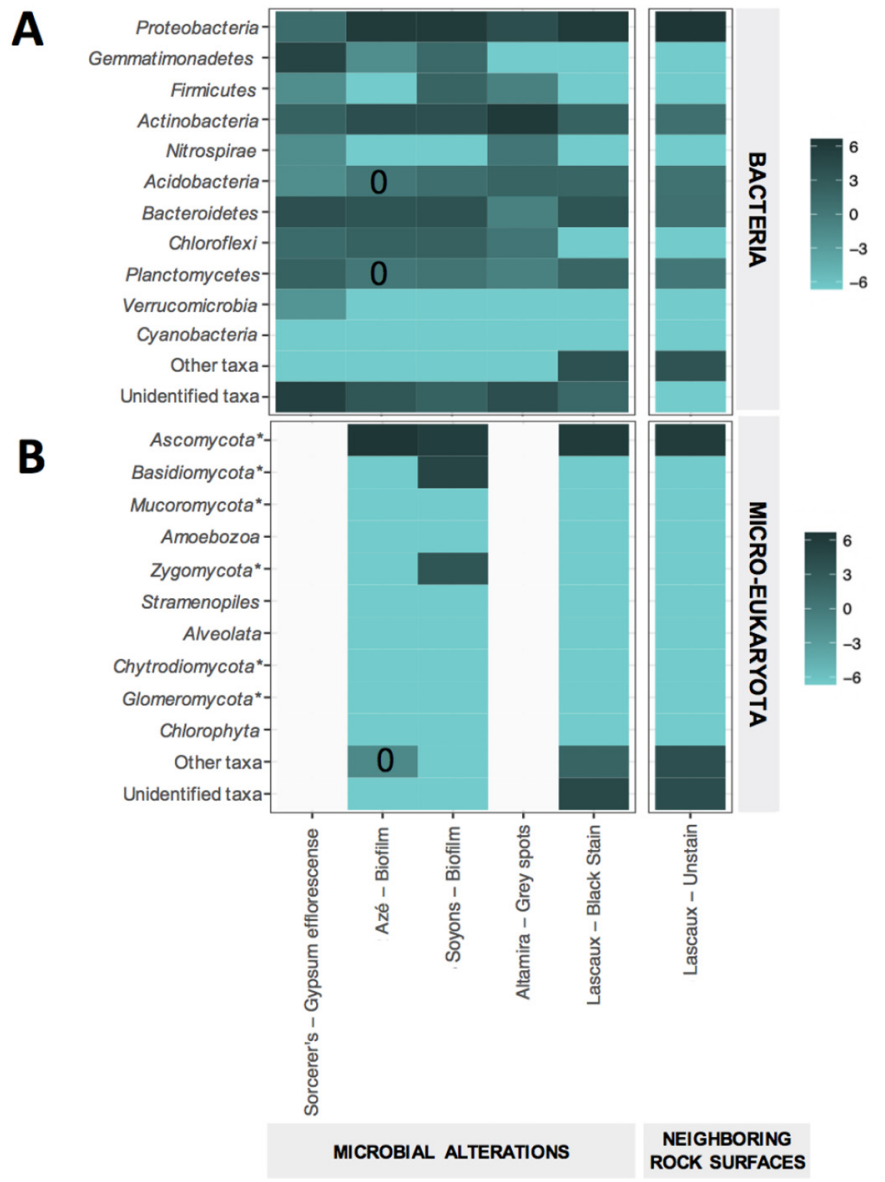

Fig. 5. Microbiome changes related to the occurrence of cave wall alterations in Paleolithic caves. Heatmaps are shown for major phyla affiliated with (A) Bacteria and (B) microeukaryotes. Sequences were retrieved in the Results section or Supplementary data of research articles (see Table S4), or in sequence databases (RDP classifier, 119 SILVA and 123 SILVA, 128 SILVA, UNITE v6, etc.). These sequences were affiliated according to the best hit obtained by BLASTn and the abundance of phyla was calculated. Heatmaps were generated using R (v.4.0.2) software with ggplot2 package (Wickham, 2016). The color intensity in each cell denotes the relative abundance the corresponding phylum, after $[\log 2(\mathrm{x}+0.01)]$ transformation: phyla of average abundance are shown in medium turquoise blue, whereas dominant phyla are in dark blue/grey and poorly-abundant phyla in light turquoise blue. A 0 value is shown for visual clarity when relative abundance of sequences is $0 \%$. White cells are used when data is not available. The asterisks indicate micro-eukaryotic phyla corresponding to fungi. See Appendix S4: Table S4 for further information on the experimental conditions that are included in the comparison. (For interpretation of the references to color in this figure legend, the reader is referred to the web version of this article.)

microorganisms is not always well documented, and especially information is scarce on the contribution of Archaea and non-fungal microeukaryotes, which might play a key role in these alterations. High-throughput sequencing methods now available have started to be implemented to assess microbial alterations, and this should help identify putative microbial actors. A more thorough description of microbial communities will also be important if the aim is to understand microbial functioning leading to surface alterations.

\subsection{Attempts to tackle microbial alterations in Paleolithic caves}

Since microbial growth and functioning on cave walls may have a deleterious impact on rock art paintings and engravings (Jurado et al., 2010; Wang et al., 2010), various corrective actions have been tested to curb microbial spread (Tiano, 2016). First, the most common corrective action is the application of antimicrobial chemicals, such as biocides (e.g. formaldehyde, hydrogen peroxide, quicklime, benzalkonium chloride, fungicides) or antibiotics (e.g. streptomycin, penicillin, polymyxin) (Dupont et al., 2007; Bastian et al., 2009a; Jurado et al., 2010), and often different chemicals are used together. In certain cases, treatments may be applied repeatedly (Dupont et al., 2007) or by alternating the types of products (Langsrud et al., 2003; Bastian et al., 2009a). The use of antimicrobials in caves has become increasingly controversial (Diaz-Herraiz et al., 2014), as they may be used as growth substrates by certain microorganisms or might promote the development of resistance mechanisms (MartinSanchez et al., 2012a), thereby favoring microbial proliferation (Stomeo et al., 2009), as developed below. Moreover, some of these chemicals may be dangerous for humans, representing a health concern for staff and visitors. Finally, certain biocides can have harmful effects on the mineral surfaces themselves, by causing discoloration, oxidation/reduction of minerals, salt formation, exfoliation, etc. (Tiano, 2016). Second, climatic conditions can be regulated to provide indirect microbial control, especially with the physical modification of passageways or the installation of airconditioning systems (Dupont et al., 2007). Third, mechanical cleaning with swabs or sponges is effective to remove microbial biomass, in particular with profuse fungal development (Jurado et al., 2010). Fourth, microbial populations may be challenged with physical methods, such as UV light (Borderie et al., 2014; Tiano, 2016). Fifth, the possibility of using microbial biocontrol agents, as tested in other cultural heritage sites (ElHagrassy, 2019), merits to be investigated. Indeed, cave isolates with antimicrobial potential have been identified (Qin et al., 2017; Belyagoubi et al., 2018; Rangseekaew and Pathom-Aree, 2019).

Chemical treatments and antibiotics, frequently used to curb microbial outgrowth in caves, may not ensure efficient control in the longer term, as some microorganisms have or develop means of resistance to these treatments (Bastian et al., 2010). Therefore, the repeated use of biocides to control certain microbial populations might, in fine, favor the development of other microbial populations and hence trigger additional and/or new alterations (Stomeo et al., 2009). In Lascaux Cave, this is likely to have facilitated the development of the white fungus Fusarium solani and later of black melanized Fungi (Martin-Sanchez et al., 2012a). The thick, melanized cell wall of these Fungi (along with Extracellular Polymeric Substance (EPS) production) confers tolerance to antimicrobial treatments (Zucconi et al., 2012). The application of quaternary ammonium compounds against algal-cyanobacterial biofilm on early Christian wall paintings in St Paul Cave (Ephesus, Turkey) favored melanized Fungi (Sterflinger and Piñar, 2013).

Resistance to the biocide benzalkonium chloride, which has been largely used in Lascaux Cave (Mauriac, 2014), is found in Gram-negative Bacteria due to cell wall properties (Nagai et al., 1996) and biofilm formation (Bastian et al., 2009a). Furthermore, some can use as carbon sources the biodegradation products of benzalkonium chloride, i.e. benzyldimethylamine, benzylamine, benzaldehyde and benzoic acid (Patrauchan and Oriel, 2003). Martin-Sanchez et al. (2012a) and Bastian et al. (2009a) highlighted diversified bacterial and fungal communities after biocide treatments in Lascaux, using cloning-sequencing methods. Biocide treatments are thought to have favored particular Bacteria, such as Ralstonia (biodegradation of xenobiotic compounds) rarely present in pristine caves (Bastian et al., 2009a; Alonso et al., 2018). Similarly, treatment with hydrochloric acid in the large cave of Arcy-sur-Cure stimulated microbial formation of calcite on artwork (Chalmin et al., 2007).

Microbial alterations in caves may be intensified by the activities of arthropods that feed on microorganisms. These arthropods act as vectors for microorganisms, such as entomopathogenic Fungi (e.g. Acremonium, Beauvaria, Geomyces, etc.) (Greif and Currah, 2007). The best described case is that of springtails (Collembola, Isotomidae) affiliated to Folsomia candida, which are opportunistic troglophiles found in caves around the world (Faddeeva-Vakhrusheva et al., 2017). They are mainly mycophagous, but they also feed on Bacteria, algae and nematodes (Bastian et al., 2009b; Bastian et al., 2010). Within Lascaux cave, these springtails are highly prevalent in black stains, suggesting a relation with black Fungi (Bastian et al., 2010; Alonso, 2018). Isotopic analysis indicated that 
Folsomia candida can consume melanized Fungi isolated from black stains (unpublished data), whereas conidia from black Fungi are disseminated by the springtail and develop in springtail feces (Bastian et al., 2010).

Therefore, it appears that many corrective actions implemented in tourist Paleolithic caves had limited success, and in some cases they were even instrumental in triggering a stronger microbial imbalance and the development of additional alteration forms, as seen with the use of chemical biocides in Lascaux (Bastian and Alabouvette, 2009; Saiz-Jimenez, 2012; Martin-Sanchez et al., 2015). More sustainable approaches, minimizing disturbance and stress on the cave microbiome, are needed to optimize conservation of cave heritage (Saiz-Jimenez et al., 2011; Mauriac, 2014).

\section{Conclusions}

The use of new generation sequencing technologies has started to shed new light on the cave microbiome, showing that the main microbial phyla prevalent in other ecosystems also predominate in caves, i.e. Proteobacteria for Bacteria, Thaumarchaeota for Archaea, and Ascomycota for Fungi. The importance of microbial dissemination as a key driver accounting for microbial presence in underground systems is long recognized, but biodiversity data also raise the possibility that certain cave microorganisms are part of metapopulations established in aboveground environments (e.g. rhizosphere, water, metazoan microbiota, etc.), which will need to be clarified further. Despite common cave features and climatic stability, cave microbiota appears to fluctuate significantly across caves or different locations within a given cave, but the underlying factors are poorly documented. This will also need to be investigated, and the development of sequencing technologies should help address this issue, as well as enable a wider exploration of the place of Archaea and protists, neglected so far, in caves. In this context, sample contamination is a critical concern with high-throughput sequencing, and it might have an impact when exploring the geographic origin of cave microbiota members. SourceTracker (Knights et al., 2011), which relies on a Bayesian approach to estimate the proportion of contaminants in community data, may be useful in future analyses of cave microbiota.

Data available to date do not indicate that Paleolithic caves would exhibit a distinct microbial community in comparison with other types of caves, but existing information remains very limited and this needs to be targeted at a larger geographic scale. In contrast, it emerges that cave anthropization related to touristic operations can be a major factor modulating microbial diversity, in caves that are Paleolithic or not. The comparison of anthropized and pristine caves points to the identification of potential bioindicator taxa, such as the Bacteroidetes (most abundant in disturbed settings) and Nitrospirae (well adapted to pristine ecological conditions), whose applicability needs to be tested in a broader range of underground conditions. So far, the analysis of cave anthropization has made incomplete use of ecological theories. For instance, mathematical tools exist to analyze complex interactions within the microbial community and they could be used to determine whether community changes related to tourism-related cave anthropization involve deterministic $v s$ stochastic processes. Quantification of these ecological processes was demonstrated successfully in the case of subsurface aquatic microbial communities (Stegen et al., 2012; Stegen et al., 2013), and they are promising to provide novel insights into cave microbiota dynamics.

Paleolithic caves are fragile environments, with outstanding conservation issues regarding the preservation of ancient artwork. In several cases, excessive frequentation of tourist Paleolithic caves resulted in microbial imbalance, with the proliferation of particular organisms associated with alterations on rock wall surface. These alterations typically occur as disconnected stains developing on walls, sometimes in the vicinity or directly on artwork. Various types of microorganisms have been evidenced on stains, such as the Cyanobacteria Scytonema julianum in lampenflora (Tito Bustillo), the Gammaproteobacteria Xanthomonadales in yellow stains (Altamira), as well as the Ascomycota Fungi Fusarium solani in white stains and pigmented Ascomycota Fungi in black stains (both instances in
Lascaux). Microbiome analyses indicated that these black pigmented Fungi were also present outside stains, but they were at levels insufficient to cause visual alteration or perhaps they were not physiologically active. This issue should be targeted in future research. Chemical treatments sometimes used to curb microbial outgrowth in tourist Paleolithic caves can cause further microbiome imbalance and lead to new alterations (e.g. black stains) implicating resistant microorganisms. Indeed, Lascaux Cave displayed an unusual microbiome when compared with other anthropized Paleolithic caves from the same region. However, little has been done so far to document microbiome changes related to cave wall alterations, and a wider assessment is needed.

Microorganisms play significant roles in cave dynamics, including in tourist Paleolithic caves, but functional knowledge is much less developed than the level of taxonomic information and requires further attention. It is therefore of prime importance to better understand the functioning of the cave microbiome (Saiz-Jimenez, 2012), and metagenomic/metatranscriptomic approaches should help fill this gap by identifying key genes and the expression of microbial functions. In the case of tourist Paleolithic caves, this could be particularly useful to decipher the formation of microbial alterations and underpin the development of sustainable cave management strategies compatible with the constraints of Paleolithic art conservation.

Supplementary data to this article can be found online at https://doi. org/10.1016/j.scitotenv.2021.151492.

\section{CRediT authorship contribution statement}

Zélia Bontemps: Writing - Original draft preparation, Resources, Visualization. Lise Alonso: Writing - Original draft preparation, Visualization. Thomas Pommier: Conceptualization, Validation. Mylène Hugoni: Visualization, Validation. Yvan Moënne-Loccoz: Funding acquisition, Project administration, Conceptualization, Writing - Review \& Editing.

\section{Declaration of competing interest}

The authors declare that they have no known competing financial interest or personal relationships that could have influenced the work reported in this paper.

\section{Acknowledgements}

Funding was provided by DRAC Nouvelle Aquitaine (Bordeaux, France). We thank S. Géraud, J.C. Portais, A. Rieu and M. Mauriac (DRAC Nouvelle Aquitaine), and Lascaux Scientific Board for helpful discussions.

\section{References}

Abdel-Haliem, M.E.F., Sakr, A.A., Ali, M.F., Ghaly, M.F., Sohlenkamp, C., 2013. Characterization of Streptomyces isolates causing colour changes of mural paintings in ancient Egyptian tombs. Microbiol. Res. 168, 428-437.

Adetutu, E.M., Thorpe, K., Bourne, S., Cao, X., Shahsavari, E., Kirby, G., Ball, A.S., 2011. Phylogenetic diversity of fungal communities in areas accessible and not accessible to tourists in Naracoorte Caves. Mycologia 103, 959-968.

Adetutu, E., Thorpe, K., Shahsavari, E., Bourne, S., Cao, X., Fard, R.M.N., Kirby, G., Ball, A., 2012. Bacterial community survey of sediments at Naracoorte Caves, Australia. Int. J. Speleol. 41, 137-147.

Ager, D., Evans, S., Li, H., Lilley, A.K., van Der Gast, C.J., 2010. Anthropogenic disturbance affects the structure of bacterial communities. Environ. Microbiol. 12, 670-678.

Alonso, L., 2018. Hétérogénéité spatio-temporelle du microbiote de la grotte de lascaux. Université de Lyon (Thèse de doctorat).

Alonso, L., Creuzé-des-Châtelliers, C., Trabac, T., Dubost, A., Moënne-Loccoz, Y., Pommier, T., 2018. Rock substrate rather than black stain alterations drives microbial community structure in the passage of Lascaux Cave. Microbiome 6, 216

Alonso, L., Pommier, T., Kaufmann, B., Dubost, A., Chapulliot, D., Doré, J., Douady, C.J., Moënne-Loccoz, Y., 2019. Anthropization level of Lascaux Cave microbiome shown by regional-scale comparisons of pristine and anthropized caves. Mol. Ecol. 28, 3383-3394.

Antranikian, G., Suleiman, M., Schäfers, C., Adams, M.W.W., Bartolucci, S., Blamey, J.M., Birkeland, N.-K., Bonch-Osmolovskaya, E., da Costa, M.S., Cowan, D., Danson, M. Forterre, P., Kelly, R., Ishino, Y., Littlechild, J., Moracci, M., Noll, K., Oshima, T., Robb, F., Rossi, M., Santos, H., Schönheit, P., Sterner, R., Thauer, R., Thomm, M., Wiegel, J., 
Stetter, K.O., 2017. Diversity of bacteria and archaea from two shallow marine hydrothermal vents from Vulcano Island. Extrem.: Life Extreme Cond. 21, 733-742.

Baffier, D., Girard, M., 1997. The karst of Arcy-sur-Cure (Yonne) and its palaeolithic human occupations. Quaternaire 8, 245-255.

Bakalowicz, M., 1999. Connaissance et gestion des ressources en eaux souterraines dans les régions karstiques. Guide Technique n³. Agence de l’Eau Rhône-Méditerranée-Corse, Lyon, France.

Banerjee, S., Joshi, S.R., 2013. Insights into cave architecture and the role of bacterial biofilm. Proc. Natl. Acad. Sci. India Sect. B Biol. Sci. 83, 277-290.

Baquedano Estévez, C., Merino, L.M., de la Losa Román, A., Valsero, J.D., 2019. The lampenflora in show caves and its treatment: an emerging ecological problem. Int. J. Speleol. 48, 249-277.

Barron, S.K., Murdock, C.A., Blair, B.G., Meade, M.E., Barger, W., 2010. Analysis of bacterial diversity in soils from blowing spring cave. J. Ala. Acad. Sci. 81, 1-10.

Barton, H.A., 2006. Introduction to cave microbiology: a review for the non-specialist. J. Cave Karst Stud. 68, 43-54.

Barton, H.A., 2015. Starving artists: bacterial oligotrophic heterotrophy in caves. In: Engel, A.S. (Ed.), Microbial Life of Cave Systems. De Gruyter, Berlin, pp. 79-104.

Barton, H.A., Jurado, V., 2007. What's up down there? Microbial diversity in caves. Microbes 2, 132-138.

Barton, H.A., Northup, D.E., 2007. Geomicrobiology in cave environments: past, current and future perspectives. J. Cave Karst Stud. 69, 163-178

Bastian, F., Alabouvette, C., 2009. Lights and shadows on the conservation of a rock art cave: the case of Lascaux Cave. Int. J. Speleol. 38, 55-60.

Bastian, F., Alabouvette, C., Jurado, V., Saiz-Jimenez, C., 2009a. Impact of biocide treatments on the bacterial communities of the Lascaux Cave. Naturwissenschaften 96, 863-868.

Bastian, F., Alabouvette, C., Saiz-Jimenez, C., 2009b. The impact of arthropods on fungal community structure in Lascaux Cave. J. Appl. Microbiol. 106, 1456-1462.

Bastian, F., Jurado, V., Nováková, A., Alabouvette, C., Saiz-Jimenez, C., 2010. The microbiology of Lascaux Cave. Microbiology (Reading, England) 156, 644-652.

Belyagoubi, L., Belyagoubi-Benhammou, N., Jurado, V., Dupont, J., Lacoste, S., Djebbah, F., Ounadjela, F., Benaissa, S., Habi, S., Abdelouahid, D., Saiz-Jimenez, C., 2018. Antimicrobial activities of culturable microorganisms (actinomycetes and fungi) isolated from Chaabe Cave, Algeria. Int. J. Speleol. 47, 189-199.

Bhullar, K., Waglechner, N., Pawlowski, A., Koteva, K., Banks, E.D., Johnston, M.D., Barton, H.A., Wright, G.D., 2012. Antibiotic resistance is prevalent in an isolated cave microbiome. PLoS ONE 7, e34953.

Biot, V., 2006. Le tourisme souterrain en France. Karstologia Mémoires 15. Association Française de Karstologie, Paris, France.

Biot, V., 2013. Les grottes ornées, des géosites culturels à la ressource territoriale. Collection EDYTEM. Cah. Géographie. 15, pp. 119-126.

Bonch-Osmolovskaya, E., Elcheninov, A., Zayulina, K., Kublanov, I., 2018. New thermophilic prokaryotes with hydrolytic activities. Microbiol. Aust. 39, 122-125.

Borderie, F., Tête, N., Cailhol, D., Alaoui-Sehmer, L., Bousta, F., Rieffel, D., Aleya, L., AlaouiSossé, B., 2014. Factors driving epilithic algal colonization in show caves and new insights into combating biofilm development with UV-C treatments. Sci. Total Environ. 484, 43-52.

Brannen-Donnelly, K., Engel, A.S., 2015. Bacterial diversity differences along an epigenic cave stream reveal evidence of community dynamics, succession, and stability. Front. Microbiol. 6, 729.

Brunet, J., Vidal, P., Vouvé, J., 1987. The Conservation of Rock Art. UNESCO, Paris, France.

Cañveras, C.S.-J., Sanchez-Moral, S., Sloer, V., 2001. Microorganisms and microbially induced fabrics in cave walls. Geomicrobiol J. 18, 223-240.

Carmichael, S.K., Zorn, B.T., Santelli, C.M., Roble, L.A., Carmichael, M.J., Bräuer, S.L., 2015. Nutrient input influences fungal community composition and size and can stimulate manganese (II) oxidation in caves. Environ. Microbiol. Rep. 7, 592-605.

Castro, H., Reddy, K.R., Ogram, A., 2002. Composition and function of sulfate-reducing prokaryotes in eutrophic and pristine areas of the Florida Everglades. Appl. Environ. Microbiol. 68, 6129-6137.

Cauche, D., 2009. Les stratégies de débitage dans les industries lithiques archaïques des premiers habitants de l'Europe. L'Anthropologie 113, 178-190.

Chalmin, E., d'Orlyé, F., Zinger, L., Charlet, L., Geremia, R.A., Orial, G., Menu, M., Baffier, D., Reiche, I., 2007. Biotic versus abiotic calcite formation on prehistoric cave paintings: the Arcy-Sur-Cure 'Grande Grotte' (Yonne, France) case. Geol. Soc. Lond. Spec. Publ. 279, 185-197.

Chen, Y., Wu, L., Boden, R., Hillebrand, A., Kumaresan, D., Moussard, H., Baciu, M., Lu, Y., Colin Murrell, J., 2009. Life without light: microbial diversity and evidence of sulfurand ammonium-based chemolithotrophy in Movile Cave. ISME J. 3, 1093-1104.

Cigna, A., 1993. Environmental management of tourist caves. Environ. Geol. 21, 173-180.

Cigna, A., 2016. Tourism and show caves. Z. Geomorphol. 60, 217-233 Supplementary Issue 2.

Cigna, A., Burri, E., 2000. Development, management and economy of show caves. Int. J. Speleol. 29, 1-27.

Cigna, A., Forti, P., Moreira, J.C., de Carvalho, C.N., 2013. Caves: the most important geotouristic feature in the world. Tour. Karst Areas 6, 9-26.

Cuezva, S., Sanchez-Moral, S., Saiz-Jimenez, C., Cañaveras, J.C., 2009. Microbial communities and associated mineral fabrics in Altamira Cave, Spain. Int. J. Speleol. 38, 83-92.

Cuezva, S., Fernandez-Cortes, A., Porca, E., Pašić, L., Jurado, V., Hernandez-Marine, M., Serrano-Ortiz, P., Hermosin, B., Cañaveras, J.C., Sanchez-Moral, S., 2012. The biogeochemical role of actinobacteria in Altamira cave, Spain. FEMS Microbiol. Ecol. 81, 281-290.

Cunnigham, K.I., DuChene, H.R., Spirakis, C.S., 1993. Elemental sulfur in caves of the Guadalupe Mountains, New Mexico. New Mexico Geological Society Guidebook 44th Field Conference, Carlsbad Region, New Mexico and West Texas, pp. 129-136.

D’Auria, G., Rojas, R., Bautista, J., Méndez, R., Gamboa, J., Goméz-Cruz, R., 2018. Metagenomics of bacterial diversity in Villa Luz caves with sulfur water springs. Genes 9,55 .
Davis, M.C., Messina, M.A., Nicolosi, G., Petralia, S., Baker, M.D., Mayne, C.K.S., Dinon, C.M., Moss, C.J., Onac, B.P., Garey, J.R., 2020. Surface runoff alters cave microbial community structure and function. PLoS ONE 15, e0232742.

De la Rosa, J.M., Martin-Sanchez, P.M., Sanchez-Cortes, S., Hermosin, B., Knicker, H., SaizJimenez, C., 2017. Structure of melanins from the fungi Ochroconis lascauxensis and Ochroconis anomala contaminating rock art in the Lascaux Cave. Sci. Rep. 7, 13441

De Leo, F., Iero, A., Zammit, G., Urzi, C.E., 2012. Chemoorganotrophic bacteria isolated from biodeteriorated surfaces in cave and catacombs. Int. J. Speleol. 41, 125-136.

De Mandal, S., Zothansanga, Panda, A.K., Bisht, S.S., Senthil Kumar, N., 2016. MiSeq HV4 16S rRNA gene analysis of bacterial community composition among the cave sediments of Indo-Burma biodiversity hotspot. Environ. Sci. Pollut. Res. Int. 23, 12216-12226.

De Mandal, S., Chatterjee, R., Kumar, N.S., 2017. Dominant bacterial phyla in caves and their predicted functional roles in C and N cycle. BMC Microbiol. 17, 90.

Dhami, N.K., Mukherjee, A., Watkin, E.L.J., 2018. Microbial diversity and mineralogicalmechanical properties of calcitic cave speleothems in natural and in vitro biomineralization conditions. Front. Microbiol. 9, 40.

Dhawi, F., 2020. Bacterial screening of historic site of Qarah caves, biosphere analysis. Agric. Biol. Res. 36, 1-4.

Diaz-Herraiz, M., Jurado, V., Cuezva, S., Laiz, L., Pallecchi, P., Tiano, P., Sanchez-Moral, S., Saiz-Jimenez, C., 2014. Deterioration of an Etruscan tomb by bacteria from the order Rhizobiales. Sci. Rep. 4, 3610.

Dupont, J., Jacquet, C., Dennetière, B., Lacoste, S., Bousta, F., Orial, G., Cruaud, C., Couloux, A., Roquebert, M.-F., 2007. Invasion of the French Paleolithic painted cave of Lascaux by members of the Fusarium solani species complex. Mycologia 99, 526-533.

ElHagrassy, A.F., 2019. Bio-restoration of mural paintings using viable cells of Pseudomonas stutzeri and characterization of these murals. Int. J. Archaeol. 7, 8-16.

Engel, A.S., 2010. Microbial diversity of cave ecosystems. In: Barton, L.L., Mandl, M., Loy, A. (Eds.), Geomicrobiology: Molecular and Environmental Perspective. Springer, Netherlands, Dordrecht, pp. 219-238.

Engel, A.S., 2019. Microbes. Chapter 83. In: White, W.B., Culver, D.C., Pipan, T. (Eds.), Academic Press, London, pp. 691-698.

Engel, A.S., Northup, D.E., 2008. Caves and karst as model systems for advancing the microbial sciences. In: Martin, J., White, W. (Eds.), Frontiers of Karst Research, Special Publication 13. Karst Water Institute, Lewisburg, PA, pp. 37-48.

Epure, L., Meleg, I.N., Munteanu, C.-M., Roban, R.D., Moldovan, O.T., 2014. Bacterial and fungal diversity of quaternary cave sediment deposits. Geomicrobiol J. 31, 116-127.

Espino del Castillo, A., Beraldi-Campesi, H., Amador-Lemus, P., Beltrán, H.I., Borgne, S.L., 2018. Bacterial diversity associated with mineral substrates and hot springs from caves and tunnels of the Naica Underground System (Chihuahua, Mexico). Int. J. Speleol. 47, 213-227.

Faddeeva-Vakhrusheva, A., Kraaijeveld, K., Derks, M.F.L., Anvar, S.Y., Agamennone, V., Suring, W., Kampfraath, A.A., Ellers, J., Le Ngoc, G., van Gestel, C.A.M., Mariën, J. Smit, S., van Straalen, N.M., Roelofs, D., 2017. Coping with living in the soil: the genome of the parthenogenetic springtail Folsomia candida. BMC Genomics 18, 493.

Garcia-Anton, E., Fernandez-Cortes, A., Alvarez-Gallego, M., Sanchez-Moral, S., Cuezva, S., Sanz-Rubio, E., Jurado, V., Porca, E., Saiz-Jimenez, C., 2013. Entry and dispersion of microorganisms inside Altamira Cave: new evidences from aerobiological and atmospheric gases surveys. In: Rogeiro-Candelera, M.A., Lazzari, M., Cano, E. (Eds.), Science and Technology for the Conservation of Cultural Heritage. CRC Press, London, pp. 55-58.

Ghosh, S., Kuisiene, N., Cheeptham, N., 2017. The cave microbiome as a source for drug discovery: reality or pipe dream? Biochem. Pharmacol. 134, 18-34.

Giraldo, A., Sutton, D.A., Samerpitak, K., de Hoog, G.S., Wiederhold, N.P., Guarro, J., Gené, J. 2014. Occurrence of Ochroconis and Verruconis species in clinical specimens from the United States. J. Clin. Microbiol. 52, 4189-4201.

Glory, A., 1964. Datation des peintures de Lascaux par le Radio-Carbone. Bull. Soc. Préhist. Fr. $61,114-117$.

Gorbushina, A.A., 2007. Life on the rocks. Env. Microbiol. 9, 1613-1631.

Gosse, J.T., Ghosh, S., Sproule, A., Overy, D., Cheeptham, N., Boddy, C.N., 2019. Whole genome sequencing and metabolomic study of cave Streptomyces isolates ICC1 and ICC4. Front. Microbiol. 10, 1020.

Greif, M.D., Currah, R.S., 2007. Development and dehiscence of the cephalothecoid peridium in Aporothielavia leptoderma shows it belongs in Chaetomidium. Mycol. Res. 111, 70-77.

Griffin, D.W., Gray, M.A., Lyles, M.B., Northup, D.E., 2014. The transport of nonindigenous microorganisms into caves by human visitation: a case study at Carlsbad Caverns National Park. Geomicrobiol. J. 31, 175-185.

Groth, I., Vettermann, R., Schuetze, B., Schumann, P., Saiz-Jimenez, C., 1999. Actinomycetes in karstic caves of northern Spain (Altamira and Tito Bustillo). J. Microbiol. Methods 36, 115-122.

Herrmann, M., Rusznyák, A., Akob, D.M., Schulze, I., Opitz, S., Totsche, K.U., Küsel, K., 2015 Large fractions of $\mathrm{CO}_{2}$-fixing microorganisms in pristine limestone aquifers appear to be involved in the oxidation of reduced sulfur and nitrogen compounds. Appl. Environ. Microbiol. 81, 2384-2394.

Hershey, O.S., Barton, H.A., 2018. The microbial diversity of caves. Chapter 5. In: Moldovan, O.T., Kováč, L., Halse, S. (Eds.), Cave Ecology, Ecological Studies 235. Springer, Cham, pp. 69-90.

Herzog Velikonja, B.H., Tkavc, R., Pasić, L., 2013. Diversity of cultivable bacteria involved in the formation of macroscopic microbial colonies (Cave silver) on the walls of a cave in Slovenia. Int. J. Speleol. 43, 45-56.

Hou, W., Dou, C., Lian, B., Dong, H., 2013. The interaction of fungus with calcite and the effects on aqueous Geochemistry in karst systems. Carbonates Evaporites 28, 413-418.

Hoyos, M., Soler, V., Cañaveras, J.C., Sánchez-Moral, S., Sanz-Rubio, E., 1998. Microclimatic characterization of a karstic cave: human impact on microenvironmental parameters of a prehistoric rock art cave (Candamo Cave, northern Spain). Environ. Geol. 33, 231-242.

Ikner, L.A., Toomey, R.S., Nolan, G., Neilson, J.W., Pryor, B.M., Maier, R.M., 2007. Culturable microbial diversity and the impact of tourism in Kartchner Caverns, Arizona. Microb. Ecol. 53, 30-42. 
Ivanova, V., Tomova, I., Kamburov, A., Tomova, A., Vasileva-Tonkova, E., Kambourova, M., 2013. High phylogenetic diversity of bacteria in the area of prehistoric paintings in Magura Cave, Bulgaria. J. Cave Karst Stud. 75, 218-228.

Jacobs, A., Msimang, D., Venter, E., 2017. First survey of the fungi from the Bakwena Cave in South Africa suggests low human disturbance. J. Cave Karst Stud. 79, 89-94.

Jones, D.S., Macalady, J.L., 2016. The snotty and the stringy: energy for subsurface life in caves. Adv. Environ. Microbiol. 1, 203-224.

Joshi, S.R., Chettri, U., 2019. Fungi in hypogean environment: bioprospection perspective. In: Satyanarayana, T., Deshmukh, S.K., Deshpande, M.V. (Eds.), Advancing Frontiers in Mycology \& Mycotechnology: Basic and Applied Aspects of Fungi. Springer, Singapore, pp. 539-561.

Jurado, V., Fernandez-Cortes, A., Cuezva, S., Laiz, L., Cañaveras, J.C., Sanchez-Moral, S., SaizJimenez, C., 2009. The fungal colonisation of rock-art caves: experimental evidence. Naturwissenschaften 96, 1027-1034.

Jurado, V., Porca, E., Cuezva, S., Fernandez-Cortes, A., Sanchez-Moral, S., Saiz-Jimenez, C., 2010. Fungal outbreak in a show cave. Sci. Total Environ. 408, 3632-3638.

Karunarathna, S.C., Dong, Y., Karasaki, S., Tibpromma, S., Hyde, K.D., Lumyong, S., Xu, J., Sheng, J., Mortimer, P.E., 2020. Discovery of novel fungal species and pathogens on bat carcasses in a cave in Yunnan Province, China. Emerg. Microbes Infect. 9, 1554-1566.

Keswick, B.H., Wang, D.-S., Gerba, C.P., 1982. The use of microorganisms as ground-water tracers: a review. Groundwater 20, 142-149.

Kiyuna, T., An, K.D., Kigawa, R., Sano, C., Miura, S., Sugiyama, J., 2011. Molecular assessment of fungi in "black spots" that deface murals in the Takamatsuzuka and Kitora Tumuli in Japan: Acremonium sect. Gliomastix including Acremonium tumulicola sp. nov. and Acremonium felinum comb. nov. Mycoscience 52, 1-17.

Knights, D., Kuczynski, J., Charlson, E.S., Zaneveld, J., Mozer, C.M., Collman, R.G., Bushman, F.D., Knight, R., Kelley, S.T., 2011. Bayesian community-wide culture-independent microbial source tracking. Nat. Meth. 8, 761-763.

Kumar, R., Kumar, A.V., 1999. Biodeterioration of Stone in Tropical Environments: An Overview. The Getty Conservation Institute, Los Angeles.

Kumaresan, D., Stephenson, J., Doxey, A.C., Bandukwala, H., Brooks, E., HillebrandVoiculescu, A., Whiteley, A.S., Murrell, J.C., 2018. Aerobic proteobacterial methylotrophs in Movile Cave: genomic and metagenomic analyses. Microbiome 6, 1-10.

Laiz, L., Groth, I., Gonzalez, I., Saiz-Jimenez, C., 1999. Microbiological study of the dripping waters in Altamira cave (Santillana del Mar, Spain). J. Microbiol. Methods 36, 129-138.

Langsrud, S., Sidhu, M.S., Heir, E., Holck, A.L., 2003. Bacterial disinfectant resistance-a challenge for the food industry. Int. Biodeterior. Biodegrad. 51, 283-290.

Le Guillou, Y., 2005. Circulations humaines et occupation de l'espace souterrain à la grotte Chauvet-Pont-d'Arc. Bull. Société Préhist. Fr. 102, 117-134.

Lefèvre, M., 1974. La 'maladie verte' de lascaux. Stud. Conserv. 19, 126-156.

Lepinay, C., Mihajlovski, A., Touron, S., Seyer, D., Bousta, F., Di Martino, P., 2018. Bacterial diversity associated with saline efflorescences damaging the walls of a French decorated prehistoric cave registered as a World Cultural Heritage Site. Int. Biodeterior. Biodegrad. $130,55-64$.

Lian, B., Yuan, D., Liu, Z., 2011. Effect of microbes on karstification in karst ecosystems. Chin. Sci. Bull. 56, 3743-3747.

Liu, Y., Whitman, W.B., 2008. Metabolic, phylogenetic, and ecological diversity of the methanogenic archaea. Ann. N. Y. Acad. Sci. 1125, 171-189.

Lü, X.-F., He, Q.F., Wang, F.K., Zhao, R.Y., Zhang, H., 2018. Impact of tourism on bacterial communities of karst underground river: a case study from two caves in Fengdu, Chongqing. Huan Jing Ke Xue 39, 2389-2399.

Mammola, S., 2019. Finding answers in the dark: caves as models in ecology fifty years after Poulson and White. Ecography 42, 1331-1351.

Man, B., Wang, H., Yun, Y., Xiang, X., Wang, R., Duan, Y., Cheng, X., 2018. Diversity of fungal communities in Heshang Cave of Central China revealed by mycobiome-sequencing. Front. Microbiol. 9, 1400

Marques, E.L.S., Dias, J.C.T., Gross, E., de Cerqueira e Silva, A.B., de Moura, S.R., Rezende, R.P., 2019. Purple sulfur bacteria dominate microbial community in Brazilian limestone cave. Microorganisms 7, 29.

Martin-Sanchez, P.M., Nováková, A., Bastian, F., Alabouvette, C., Saiz-Jimenez, C., 2012a. Use of biocides for the control of fungal outbreaks in subterranean environments: the case of the Lascaux Cave in France. Environ. Sci. Technol. 46, 3762-3770.

Martin-Sanchez, P.M., Nováková, A., Bastian, F., Alabouvette, C., Saiz-Jimenez, C., 2012b. Two new species of the genus Ochroconis, O. lascauxensis and O. anomala isolated from black stains in Lascaux Cave, France. Fungal Biol. 116, 574-589.

Martin-Sanchez, P.M., Miller, A.Z., Saiz-Jimenez, C., 2015. Lascaux Cave: an example of fragile ecological balance in subterranean environments. In: Engel, A.S. (Ed.), Microbial Life in Cave Systems. De Gruyter, Berlin/Boston, pp. 279-301.

Mauriac, M., 2014. Lascaux: preserving a 20 000-year old legacy of Paleolithic art. Medicographia 36, 238-252.

Mihajlovski, A., Lepinay, C., Mirval, A.-L., Touron, S., Bousta, F., Di Martino, P., 2019. Characterization of the archaeal and fungal diversity associated with gypsum efflorescences on the walls of the decorated Sorcerer's prehistoric cave. Ann. Microbiol. $69,1071-1078$

Ministère de la Culture et de la Communication, 2020. Art rupestre et grottes ornées. URL https://www.culture.gouv.fr/Sites-thematiques/Archeologie/Centre-national-deprehistoire-Art-rupestre-Grottes-ornees/Art-rupestre-Grottes-ornees (accessed 5.19.20).

Mohen, J., Taborin, Y., 2009. Les sociétés de la préhistoire. Hachette Supérieur, Paris.

Moissl-Eichinger, C., Huber, H., 2011. Archaeal symbionts and parasites. Curr. Opin. Microbiol. 14, 364-370.

Morse, K.V., Richardson, D.R., Brown, T.R., Vangundy, R.D., Cahoon, A.B., 2021. Longitudinal metabarcode analysis of karst bacterioplankton microbiomes provide evidence of epikarst to cave transport and community succession. PeerJ 9, e10757.

Mulec, J., Oarga-Mulec, A., Šturm, S., Tomazin, R., Matos, T., 2017. Spacio-temporal distribution and tourist impact on airborne bacteria in a cave (Škocjan caves, Slovenia). Diversity 9, 28.
Nagai, K., Ohta, S., Zenda, H., Matsumoto, H., Makinom, M., 1996. Biochemical characterization of a Pseudomonas fluorescens strain isolated from a benzalkonium chloride solution. Biol. Pharm. Bull. 19, 873-875.

Nehme, C., 2013. The use of passive seismological imaging in speleogenetic studies; an example from Kanaan Cave, Lebanon. Int. J. Speleol. 42, 97-108.

Northup, D.E., 1997. Balancing Conservation of Unusual Cave Microbial Communities With Exploration and Research in Lechuguilla Cave, Carlsbad Caverns. National Park, New Mexico. Final Report to the Anne D. Morrow and Charles A. Lindbergh Foundation and the National Park Service.

Northup, D., Lavoie, K., 2001. Geomicrobiology of caves: a review. Geomicrobiol J. 18, 199-222.

Northup, D.E., Carr, D.L., Crocker, M.T., Cunningham, K.I., Hawkins, L.K., Leonard, P., Welbourn, W.C., 1994. Biological investigations in Lechuguilla Cave. J. Cave Karst Stud. 56, 54-63.

Northup, D.E., Barns, S.M., Yu, L.E., Spilde, M.N., Schelble, R.T., Dano, K.E., Crossey, L.J., Connolly, C.A., Boston, P.J., Natvig, D.O., Dahm, C.N., 2003. Diverse microbial communities inhabiting ferromanganese deposits in Lechuguilla and Spider Caves. Environ. Microbiol. 5, 1071-1086.

Novakova, A., Elhottová, D., Kristufek, V., Lukesova, A., Hill, P., Kovac, L., Mock, A., Luptacik, P., 2005. Feeding sources of invertebrates in Ardovská Cave and Domica Cave systems - preliminary results. In: Tajovský, K., Schlaghamerský, J., Pižl, V. (Eds.), Contributions to Soil Zoology in Central Europe. Biology Centre AS CR, České Budějovice, pp. 107-112.

Ogórek, R., Višňovská, Z., Tančinová, D., 2016. Mycobiota of underground habitats: case study of Harmanecká Cave in Slovakia. Microb. Ecol. 71, 87-99.

Ortiz, M., Legatzki, A., Neilson, J.W., Fryslie, B., Nelson, W.M., Wing, R.A., Soderlund, C.A., Pryor, B.M., Maier, R.M., 2014. Making a living while starving in the dark: metagenomic insights into the energy dynamics of a carbonate cave. ISME J. 8, 478-491.

Palmer, A.N., 1991. Origin and morphology of limestone caves. Geol. Soc. Am. Bull. 103, $1-21$.

Pasić, L., Kovce, B., Sket, B., Herzog-Velikonja, B., 2010. Diversity of microbial communities colonizing the walls of a Karstic cave in Slovenia. FEMS Microbiol. Ecol. 71, 50-60.

Patrauchan, M.A., Oriel, P.J., 2003. Degradation of benzyldimethylalkylammonium chloride by Aeromonas hydrophila sp. K. J. Appl. Microbiol. 94, 266-272.

Perrette, Y., Delannoy, J.-J., Bolvin, H., Cordonnier, M., Destombes, J.-L., Zhilinskaya, E.A., Aboukais, A., 2000. Comparative study of a stalagmite sample by stratigraphy, laser induced fluorescence spectroscopy, EPR spectrometry and reflectance imaging. Chem. Geol. 162, 221-243.

Pfendler, S., Karimi, B., Maron, P.-A., Ciadamidaro, L., Valot, B., Bousta, F., Alaoui-Sosse, L., Alaoui-Sosse, B., Aleya, L., 2018. Biofilm biodiversity in French and Swiss show caves using the metabarcoding approach: first data. Sci. Total Environ. 615, 1207-1217.

Pike, A.W.G., Hoffmann, D.L., García-Diez, M., Pettitt, P.B., Alcolea, J., Balbín, R.D., GonzálezSainz, C., de las Heras, C., Lasheras, J.A., Montes, R., Zilhão, J., 2012. U-series dating of Paleolithic art in 11 caves in Spain. Science 336, 1409-1413.

Porter, M.L., Engel, A.S., Kane, T.C., Kinkle, B.K., 2009. Productivity-diversity relationships from chemolithoautotrophically based sulfidic karst systems. Int. J. Speleol. $38,27-40$.

Portillo, M.C., Gonzalez, J.M., 2010. Differential effects of distinct bacterial biofilms in a cave environment. Curr. Microbiol. 60, 435-438.

Portillo, M.C., Gonzalez, J.M., Saiz-Jimenez, C., 2008. Metabolically active microbial communities of yellow and grey colonizations on the walls of Altamira Cave, Spain. J. Appl. Microbiol. 104, 681-691.

Portillo, M.C., Saiz-Jimenez, C., Gonzalez, J.M., 2009. Molecular characterization of total and metabolically active bacterial communities of "white colonizations" in the Altamira Cave, Spain. Res. Microbiol. 160, 41-47.

Prescott, L.-M., Willey, J.M., Sherwood, L.M., Woolwerton, C.J., 2018. Microbiology. 5th edn. De Boeck, Louvain-la-Neuve.

Qin, Y., Fu, Y., Kang, W., Li, H., Gao, H., Vitalievitch, K.S., Liu, H., 2017. Isolation and identification of a cold-adapted bacterium and its characterization for biocontrol and plant growth-promoting activity. Ecol. Eng. 105, 362-369.

Rangseekaew, P., Pathom-Aree, W., 2019. Cave Actinobacteria as producers of bioactive metabolites. Front. Microbiol. 10, 387.

Riding, R., 2000. Microbial carbonates: the geological record of calcified bacterial-algal mats and biofilms. Sedimentology 47, 179-214.

Roldán, M., Hernández-Mariné, M., 2009. Exploring the secrets of the three-dimensional architecture of phototrophic biofilms in caves. Int. J. Speleol. 38, 41-53.

Russell, A.D., 1998. Mechanisms of bacterial resistance to antibiotics and biocides. Prog. Med. Chem. 35, 133-197.

Russell, M.J., MacLean, V.L., 2008. Management issues in a Tasmanian tourist cave: potential microclimatic impacts of cave modifications. J. Environ. Manag. 87, 474-483.

Rusterholtz, K.J., Mallory, L.M., 1994. Density, activity, and diversity of bacteria indigenous to a karstic aquifer. Microb. Ecol. 28, 79-99.

Rusznyák, A., Akob, D.M., Nietzsche, S., Eusterhues, K., Totsche, K.U., Neu, T.R., Frosch, T. Popp, J., Keiner, R., Geletneky, J., Katzschmann, L., Schulze, E.-D., Küsel, K., 2012. Calcite biomineralization by bacterial isolates from the recently discovered pristine karstic Herrenberg cave. Appl. Environ. Microbiol. 78, 1157-1167.

Saiz-Jimenez, C., 2012. Microbiological and environmental issues in show caves. World J. Microbiol. Biotechnol. 28, 2453-2464.

Saiz-Jimenez, C., Hermosin, B., 1999. Thermally assisted hydrolysis and methylation of dissolved organic matter in dripping waters from the Altamira Cave. J. Anal. Appl. Pyrolysis 49, 337-347.

Saiz-Jimenez, C., Cuezva, S., Jurado, V., Fernandez-Cortes, A., Porca, E., Benavente, D., Cañaveras, J.C., Sanchez-Moral, S., 2011. Paleolithic art in peril: policy and science collide at Altamira Cave. Science 334, 42-43.

Samerpitak, K., Gerrits van den Ende, A.H.G., Menken, S.B.J., de Hoog, G.S., 2015. Three new species of the genus Ochroconis. Mycopathologia 180, 7-17. 
Sand, W., 1997. Microbial mechanisms of deterioration of inorganic substrates-a general mechanistic overview. Int. Biodeter. Biodegrad. 40, 183-190.

Sauvadet, A.-L., Gobet, A., Guillou, L., 2010. Comparative analysis between protist communities from the deep-sea pelagic ecosystem and specific deep hydrothermal habitats. Environ. Microbiol. 12, 2946-2964.

Sauvet, G., 2015. À la recherche du temps perdu. Méthodes de datations en art préhistorique: l'exemple des sites aurignaciens. Palethnologie 7, 210-225.

Schabereiter-Gurtner, C., Saiz-Jimenez, C., Piñar, G., Lubitz, W., Rölleke, S., 2002. Altamira cave Paleolithic paintings harbor partly unknown bacterial communities. FEMS Microbiol. Lett. 211, 7-11.

Schabereiter-Gurtner, C., Saiz-Jimenez, C., Piñar, G., Lubitz, W., Rölleke, S., 2004. Phylogenetic diversity of bacteria associated with Paleolithic paintings and surrounding rock walls in two Spanish caves (Llonín and La Garma). FEMS Microbiol. Ecol. 47, 235-247.

Scheu, S., Simmerling, F., 2004. Growth and reproduction of fungal feeding Collembola as affected by fungal species, melanin and mixed diets. Oecologia 139, 347-353.

Schleper, C., Jurgens, G., Jonuscheit, M., 2005. Genomic studies of uncultivated archaea. Nat. Rev. Microbiol. 3, 479-488.

Schoch, C.L., Sung, G.-H., López-Giráldez, F., Townsend, J.P., Miadlikowska, J., Hofstetter, V., Robbertse, B., Matheny, P.B., Kauff, F., Wang, Z., Gueidan, C., Andrie, R.M., Trippe, K., Ciufetti, L.M., Wynns, A., Fraker, E., Hodkinson, B.P., Bonito, G., Groenewald, J.Z., Arzanlou, M., Sybren de Hoog, G., Crous, P.W., Hewitt, D., Pfister, D.H., Peterson, K., Gryzenhout, M., Wingfield, M.J., Aptroot, A., Suh, S.-O., Blackwell, M., Hillis, D.M., Griffith, G.W., Castlebury, L.A., Rossman, A.Y., Lumbsch, H.T., Lücking, R., Büdel, B., Rauhut, A., Diederich, P., Ertz, D., Geiser, D.M., Hosaka, K., Inderbitzin, P., Kohlmeyer, J., Volkmann-Kohlmeyer, B., Mostert, L., O’Donnell, K., Sipman, H., Rogers, J.D., Shoemaker, R.A., Sugiyama, J., Summerbell, R.C., Untereiner, W., Johnston, P.R., Stenroos, S., Zuccaro, A., Dyer, P.S., Crittenden, P.D., Cole, M.S., Hansen, K., Trappe, J.M., Yahr, R., Lutzoni, F., Spatafora, J.W., 2009. The Ascomycota tree of life: a phylum-wide phylogeny clarifies the origin and evolution of fundamental reproductive and ecological traits. Syst. Biol. 58, 224-239.

Simon, K.S., 2019. Cave ecosystems. Chapter 26. In: White, W.B., Culver, D.C., Pipan, T. (Eds.), Encyclopedia of Caves, 3rd ed. Academic Press, London, pp. 223-226.

Snider, J.R., Goin, C., Miller, R.V., Boston, P.J., Northup, D.E., 2009. Ultraviolet radiation sensitivity in cave bacteria: evidence of adaptation to the subsurface? Int. J. Speleol. 38, $11-22$.

Stegen, J.C., Lin, X., Konopka, A.E., Fredrickson, J.K., 2012. Stochastic and deterministic assembly processes in subsurface microbial communities. ISME J. 9, 1653-1664.

Stegen, J.C., Lin, X., Fredrickson, J.K., Chen, X., Kennedy, D.W., Murray, C.J., Konopka, A., 2013. Quantifying community assembly processes and identifying features that impose them. ISME J. 11, 2069-2079.

Sterflinger, K., 1998. Temperature and NaCl- tolerance of rock-inhabiting meristematic fungi. Antonie Van Leeuwenhoek 74, 271-281.

Sterflinger, K., Piñar, G., 2013. Microbial deterioration of cultural heritage and works of arttilting at windmills? Appl. Microbiol. Biotechnol. 97, 9637-9646.

Stomeo, F., Portillo, M.C., Gonzalez, J.M., 2009. Assessment of bacterial and fungal growth on natural substrates: consequences for preserving caves with prehistoric paintings. Curr. Microbiol. 59, 321-325.

Stupar, M., Grbić, M.L., Džamić, A., Unković, N., Ristić, M., Jelikić, A., Vukojević, J., 2014. Antifungal activity of selected essential oils and biocide benzalkonium chloride against the fungi isolated from cultural heritage objects. South Afr. J. Bot. 93, 118-124.

Thimm, T., Hoffmann, A., Borkott, H., Munch, J.C., Tebbe, C.C., 1998. The gut of the soil microarthropod Folsomia candida (Collembola) is a frequently changeable but selective habitat and a vector for microorganisms. Appl. Environ. Microbiol. 64, 2660-2669.

Thompson, B., Richardson, D., Vangundy, R.D., Cahoon, A.B., 2019. Metabarcoding comparison of prokaryotic microbiomes from Appalachian karst caves to surface soils in southwest Virginia, USA. J. Cave Karst Stud. 81, 244-253.

Tiano, P., 2016. Biodeterioration of stone monuments a worldwide issue. Open Conf. Proc. J. 7, 29-38.
Tomczyk-Żak, K., Zielenkiewicz, U., 2016. Microbial diversity in caves. Geomicrobiol. J. 33, 20-38.

Turrini, P., Tescari, M., Visaggio, D., Pirolo, M., Lugli, G.A., Ventura, M., Frangipani, E., Visca, P., 2020. The microbial community of a biofilm lining the wall of a pristine cave in Western New Guinea. Microbiol. Res. 241, 126584.

Urzì, C., De Leo, F., Bruno, L., Albertano, P., 2010. Microbial diversity in Paleolithic caves: a study case on the phototrophic biofilms of the Cave of Bats (Zuheros, Spain). Microb. Ecol. 60, 116-129.

Valladas, H., Tisnérat-Laborde, N., Cacher, H., Kaltnecker, E., Arnold, M., Oberlin, C., Evin, J. 2005. Bilan des datations carbone 14 effectuées sur des charbons de bois de la grotte Chauvet. Bull. Soc. Préhist. Fr. 102, 109-113.

Vanderwolf, K.J., Malloch, D., McAlpine, D.F., Forbes, G.J., 2013. A world review of fungi, yeasts, and slime molds in caves. Int. J. Speleol. 42, 77-96.

Vaughan, M., Maier, R., Pryor, B., 2011. Fungal communities on speleothem surfaces in Kartchner Caverns, Arizona, USA. Int. J. Speleol. 40, 65-77.

Verde, G., 2000. Il termalesmo di Sciacca, dalla preistoria al XX secolo. Industria Grafica T. Sarcuto, Agrigento, Italy.

Wang, W., Ma, X., Ma, Y., Mao, L., Wu, F., Ma, X., An, L., Feng, H., 2010. Seasonal dynamics of airborne fungi in different caves of the Mogao Grottoes, Dunhuang, China. Int. Biodeterior. Biodegrad. 64, 461-466.

Wasti, I.G., Seelan, J.S.S., 2019. The fungal diversity of Madai Cave, Sabah, Malaysia. Proceedings of the Langkawi International Multidisciplinary Academic Conference (LIMAC). Asian Scholars Network, Pulau Langkawi, Malaysia, pp. 264-274.

Wickham, H., 2016. ggplot2: Elegant Graphics for Data Analysis. Second edition. Springer International Publishing, Heidelberg.

Wiseschart, A., Mhuantong, W., Tangphatsornruang, S., Chantasingh, D., Pootanakit, K., 2019. Shotgun metagenomic sequencing from Manao-Pee cave, Thailand, reveals insight into the microbial community structure and its metabolic potential. BMC Microbiol. 19, 144

Xiong, W., Jousset, A., Guo, S., Karlsson, I., Zhao, Q., Wu, H., Kowalchuk, G.A., Shen, Q., Li, R., Geisen, S., 2018. Soil protist communities form a dynamic hub in the soil microbiome. ISME J. 12, 634-638.

Yun, Y., Xiang, X., Wang, H., Man, B., Gong, L., Liu, Q., Dong, Q., Wang, R., 2016. Five-year monitoring of bacterial communities in dripping water from the Heshang Cave in Central China: implication for paleoclimate reconstruction and ecological functions. Geomicrobiol. J. 33, 1-11.

Zepeda Mendoza, M.L., Lundberg, J., Ivarsson, M., Campos, P., Nylander, J.A.A., Sallstedt, T., Dalen, L., 2016. Metagenomic analysis from the interior of a speleothem in Tjuv-Ante's cave, northern Sweden. PLoS ONE 11, e0151577.

Zhang, Z.-F., Cai, L., 2019. Substrate and spatial variables are major determinants of fungal community in karst caves in Southwest China. J. Biogeogr. 46, 1504-1518.

Zhang, Z.F., Zhao, P., Cai, L., 2018. Origin of cave fungi. Front. Microbiol. 9, 1407.

Zheng, Q., Hu, Y., Zhang, S., Noll, L., Böckle, T., Dietrich, M., Herbold, C.W., Eichorst, S.A., Woebken, D., Richter, A., Wanek, W., 2019. Soil multifunctionality is affected by the soil environment and by microbial community composition and diversity. Soil Biol. Biochem. 136, 107521.

Zhu, H.-Z., Zhang, Z.-F., Zhou, N., Jiang, C.-Y., Wang, B.-J., Cai, L., Liu, S.-J., 2019. Diversity, distribution and co-occurrence patterns of bacterial communities in a karst cave system. Front. Microbiol. 10, 1726.

Ziganshina, E.E., Mohammed, W.S., Shagimardanova, E.I., Vankov, P.Y., Gogoleva, N.E., Ziganshin, A.M., 2018. Fungal, bacterial, and archaeal diversity in the digestive tract of several beetle larvae (Coleoptera). BioMed. Res. Int. 2018, 6765438.

Zorn, B., 2014. Illumina Sequencing of Fungal Assemblages Reveals Compositional Shifts as a Result of Nutrient Loading Within Cave Sediments. Appalachian State University, Boone, NC Doctoral dissertation.

Zucconi, L., Gagliardi, M., Isola, D., Onofri, S., Andaloro, M.C., Pelosi, C., Pogliani, P., Selbmann, L., 2012. Biodeterioration agents dwelling in or on the wall paintings of the Holy Saviour's cave (Vallerano, Italy). Int. Biodeterior. Biodegrad. 70, 40-46. 